Kader

e-ISSN: 2602-2710

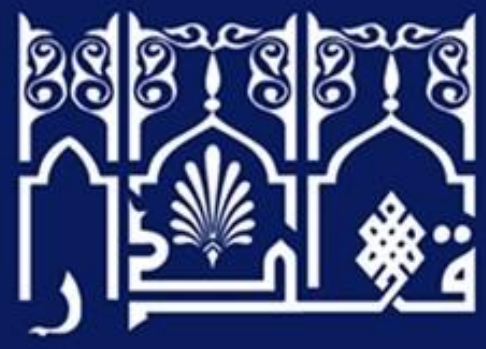

Cilt: 19, Say1: 2, 2021, ss. 471-493

Volume: 19, Issue: 2, 2021, pp. 471-493

\title{
Bir Kelam Problemi Olarak İlâhî Vahyin Korunmuşluğu Meselesi
}

The Issue of the Preservation of Divine Revelation in Kalām

\section{Hilmi Kemal ALTUN}

Dr. Öğr. Üyesi, Adıyaman Üniversitesi, İslami İlimler Fakültesi, Adıyaman/Türkiye Assistant Professor Dr., Adıyaman University, Faculty of Islamic Sciences, Adıyaman/ Türkiye kaltun42@hotmail.com | orcid.org/0000-0002-3583-5142 | ror.org/02s4gkg68

\author{
Makale Bilgisi Article Information \\ Makale Türü Article Type \\ Araştırma Makalesi Research Article \\ Geliş Tarihi Date Recieved \\ 25 Ağustos $2021 \quad 25$ August 2021 \\ Kabul Tarihi Date Accepted \\ 30 Kasım 202130 November 2021 \\ Yayın Tarihi Date Published \\ 31 Aralk 202131 December 2021 \\ Intihal Plagiarism
}

Bu makale, iTenticate yazılımı ile taranmıştır. İntihal This article has been scanned with iTenticate

tespit edilmemiştir. software. No plagiarism detected.

Etik Beyan Ethical Statement

Bu çalışmanın hazırlanma sürecinde bilimsel ve etik It is declared that scientific and ethical principles ilkelere uyulduğu ve yararlanılan tüm çalışmaların have been followed while carrying out and writing kaynakçada belirtildiği beyan olunur (Hilmi Kemal this study and that all the sources used have been Altun). properly cited (Hilmi Kemal Altun).

CC BY-NC-ND 4.0 lisansı ile lisanslanmıştır. Licensed under CC BY-NC-ND 4.0 license.

Atıf $\mid$ Cite As

cc Altun, Hilmi Kemal. "Bir Kelam Problemi Olarak illâhî Vahyin Korunmuşluğu Meselesi”. Kader 19/2 (Aralık 2021), 471-493. https://doi.org/10.18317/kaderdergi.987097 


\title{
Öz
}

Kitaplara iman bahsinde tartışılan konulardan biri de vahyin korunması meselesidir. Konu etrafında yanıtlanmayı bekleyen birtakım sorular vardır. Söz gelimi "vahyin korunması” gerek Kur'an açısından gerekse önceki vahiy metinleri açısından mümkün müdür? İmkân ya da imkânsızlığın tarihsel ve sosyolojik gerçeklik açısından sebepleri nelerdir? Şayet korunma mümkünse kaynağı ilâhî otorite midir yoksa beşerî unsurlar mıdır? ìlâhî otorite ön planda ise bu otorite yalnızca Kur'an hakkında mı tecelli etmiştir? Bu yönüyle Kur'an'la ilgili öncekilerden farklı bir uygulama olabilir mi? şeklinde pek çok problem peş peşe sıralanabilir. Aynı şekilde Kur'an'ın nüzûlünden itibaren hiçbir değişim ve tahrife maruz kalmaksızın günümüze kadar intikal edişi, akıllara diğer kitapların neden bu nitelikten mahrum olduğu sorusunu getirmektedir. Bu meyanda verilen cevaplar Kur'an'ın diğerlerinden farklı olarak "ilâhî koruma altında olduğu” bu nedenle tebdil ve tahrifine imkân olmadığı argümanına dayanmaktadır. Bu cevaba İslâm dininin son ve evrensel oluşu gibi faktörlerin de eklenmesiyle Kur'an ve diğer kitaplar arasındaki fark açıklanmaya çalışılmaktadır. Ancak meselenin bu haliyle hallolduğunu, verilen cevapların özellikle entelektüel zihinler açısından tam bir berraklık oluşturduğunu söylemek güçtür. Ayrıca Kur'an üzerinde ilâhî iltimas olduğu algısını oluşturacak tarzda yapılan bu tür yorumların tarihsel analizlerinin yapılması gerekmektedir. Bu çalışmada öncelikle Tevrat, Zebûr ve İncil'in orijinal hallerini koruyup koruyamadıkları meselesi kısaca tartışılmış, ardından dikkatler Kur'an üzerine çekilmiştir. Bu çerçevede sıklıkla atıf yapılan el-Hicr 15/9 âyeti etrafında yapılan yorumlar irdelenmiş ve erken dönem müfessirlerince bu âyet Kur'an'ın daha çok nüzûl sürecini ilgilendiren bir korunmaya dikkat çekildiği görülmüştür. Özellikle hicrî ilk 3 asırda yazılan tefsirlerde Kur'an'ın korunması meselesinin nüzûl süreciyle ilişkili olarak ele alınması; korumanın Allah ile Hz. Peygamber arasındaki bir sürece tahsis edilmiş olması anlamlıdır. Buna karşın sonraki dönemlerde yazılan tefsirlerde ise yorumların Kur'an'ın ilelebet ilâhî koruma garantisi altında olduğu yönüne evirildiği görülmektedir. Tefsirlerde söz konusu âyetin yorumundaki bu değişikliğin sebeplerinin neler olabileceği noktasında yaptığımız çalışmada iki temel nedene ulaştık. Birincisi nüzûl ortamından uzaklaşılmış olmasıdır. İkincisi ise söz konusu âyetin, tarihsel süreçte Kur'an'dan bir kısım sûre ve âyetlerin çıkarıldığını ileri süren Şiî düşüncenin reddine yönelik yorumlanmaya elverişli olmasıdır. Dolayısıyla tefsirlerde söz konusu âyet bağlamında değişen yorum farkının temelinde mezhebî sâiklerin olduğunu söylemek mümkündür. Çalışmamızda da görüleceği üzere bahsi geçen âyette Kur'an'ın korunma sürecini anlatan ifadeler -özellikle erken dönem müfessirlerinin kanaatinden hareketle- nüzûl aşamasını ifade ettiği için İlâhî koruma garantisi açısından Kur'an'ın diğer kitaplardan farkının olmadığını söylemek mümkündür.

Anahtar Kelimeler: Kelâm, Vahiy, Tevrat, İncil, Kur’an, i̇lâhî koruma.

\begin{abstract}
One of the issues discussed about the subject of faith in divine scripture is the preservation of the revelation. For instance, is "the preservation of revelation" possible both in terms of the Qur'ān and previous texts of revelation? What are the reasons for its possibility or impossibility with reference to the historical and sociological reality? If protection is possible, is its source the divine authority or human elements? If the divine authority is dominant, did this authority only manifest itself in the Qur'ān? Could the Qurān be different in this respect than the previous holy books? Likewise, the recognition that the Qur'ān has survived to the present day without any changes or distortion since its revelation leads to the question of why other books lacked this quality. The answers for this question are based on the argument that the Qur'ān, unlike other holy scripts, is "under divine protection"; therefore, it is not possible to change or distort it. Thus, the study first briefly discusses issue of whether the Torah, Psalms and the Gospel preserved their originality and then draws attention to the Qur'ān. Although the protection of the authenticity of the Qur'ān is beyond dispute, the nature of this preservation and what stages it covers are controversial. In this context, the interpretations commonly made regarding the commonly cited the verse of Surah al-Hijr (15/9) were examined, and this verse was majorly interpreted by the early commentators as the preservation of the Qur'ān which concerns the revelation process. In the tafsirs written in the first three Hijri centuries in particular, it makes sense that the issue of the preservation of the Qur'ān is addressed in relation to the process of its revelation and that the protection relates to a process in which Allah and the Prophet were involved. On the other hand, in the commentaries written in later times, it is clearly seen that the interpretations evolved into the idea that the Qur'ān is under the guarantee of divine protection forever. In the present study, which was carried out to reveal what could be the reasons for the change in the interpretations of the aforementioned verse in the commentaries, we discovered particular reasons. Therefore, one could say that there are sectarian motives underlying the different interpretations of the verse in question.
\end{abstract}

Keywords: Kalām, Revelation, Divine Protection, Torah, Gospel, Qur’ān. 


\section{Giriş}

Allah Teâlâ insanoğlunu yarattıktan sonra onunla iletişimini peygamberler ve onlara indirdiği vahiyler aracıllğ̆ıla gerçekleştirmiştir. Allah'ın insanı imtihan dünyası olan bu hayatta başıboş bırakmama gayesiyle ilâhî lütuf kabilinden gönderdiği bu vahiyler, peygamberlerin hayatlarıyla sınırlı kalmamıştır. Zira beşer türü olmaları peygamberlerin ölümlü olmasını gerektirirken, ilâhî mesaj da maksadı ve fonksiyonu açısından sürekli olmayı icap ettirmektedir. Nitekim öyle de olmuştur. Allah'ın ilk insanla birlikte gönderdiği akideye konu olan temel nitelikler asliyetini muhafaza etmiştir. Bu niteliklerin tevhit, nübüvvet, melek, ahiret inancı gibi temel itikadî umdeler olduğunu söylemek mümkündür. Dinin usul ve fürû kısmının bulunduğu düşünüldüğünde bahsedilen niteliklerin usulle ilgili olduğu anlaşılmaktadır. Buna Allah'ın ilk insana gönderdiği dinin adı olan İslâm'ın ilkeleri demek de mümkündür. Nitekim “Allah katında din İslâm'dır" âyetinde de bu gerçeğe işaret edilmektedir. Bununla birlikte dinin dinamik tarafını teşkil eden ameli-fikhî boyutu da vardır ki dinin bu tür emirleri zamana göre değişen kısmını oluşturmaktadır. ilâhî kitaplar, asliyetlerini korudukları müddetçe dinin her iki yönünü de ihtiva eden mesajlar barındırmaktadır. Ne var ki geçmiş vahiylerin varislerine bakıldığında itikat ve amele kaynaklık etme açısından kendilerine inzâl olunan vahyi orijinal haliyle muhafaza edemedikleri görülmektedir. Ayrıca beşerin mevcut zihnî gelişmişlik halinden hareketle insanlığın evrendeki ilk serüveninden itibaren vahyolunan her bilgiyi muhafaza etmenin mümkün olmadığını, fizikî ve teknik imkânların bu hususta elverişli olmadığını söylemek âfâkî bir söylem olmasa gerektir. Mamafih kutsal metin oldukları iddiasıyla elimizde bulunan nüshalar hakkındaki tarih boyu süregelen şüpheler ve ulaşılan sonuçlar da bizi bu yönde birtakım çıkarımlarda bulunmaya sevk etmektedir. Öncelikle muhteva ve teknik açıdan yapılan tahliller, Tevrat ve İncil gibi kutsal kitap hüviyetindeki metinlerin doğrudan İlâhî mesajın kendisi olmadığını ispat etmektedir. Ayrıca gerek kronolojik gerekse de bilimsel metotlarla yapılan mukayeseler, söz konusu eserler hakkında bütünlüklü bir korumanın pek de mümkün olmadığını ispatlar mahiyettedir. Ancak Kur'an'ın diğer metinlerle arasında bu açıdan bariz bir fark bulunmaktadır. Diğerlerinden farklı olarak Kur'an, inzâl olduğu andan itibaren bugüne kadar titizlikle korunarak gelmiştir. İşte tam da bu noktada, yani Kur'an'ın diğerlerinden farklı olarak korunarak gelmesinde müessir unsur beşerî faktörler, kevnî sebepler/doğal süreçler midir yoksa doğrudan Kur'an'ın korunmasına yönelik Kur'an'da yer alan ilâhî tekeffül vaadi ve bu vaade dayalı olarak îlâhî Otorite'nin korumaya devam ediyor olması mıdır?

Bu amaçla Kur'an'dan önceki vahiy mahsulü olduğu bilinen metinlerin korunamamış olmalarının sebepleri tahlil edilecek ardından onlardan farklı olarak Kur'an'ın "korunarak" gelmesinin anlamı ve mahiyeti üzerinde durulacaktır. Herhangi bir tebdil ve tahrife uğramadığı konusunda şüphe bulunmayan Kur'an'ın sahip olduğu müstesna vasfın, ilâhî garantörlük sonucu mu yoksa daha çok beşerî faktörlerle mi olduğu hususuna temas edilecektir. Bu bağlamda sıklıkla örnek gösterilen elHicr 15/9 âyetinin yorumlanmasında ilk dönem müfessirleriyle sonraki dönem arasındaki farklılığın muhtemel sebepleri üzerinde durulacaktır. Konunun kelamla ilişkisine gelince hiç şüphesiz ki bütün nitelikleriyle mutlak anlamda vahyin kendisi İslam inancının temel

1 Hayrettin Karaman, Mustafa Çağrıcı vd., Kur'an Yolu Türkçe Meal ve Tefsir (Ankara: Diyanet İşleri Başkanlığı Yayınları, 2006), Âl-i İmrân 3/19. 
kaidelerinden birisi olan kitaplara iman konusunun temelini teşkil etmektedir. Bu çerçevede elimizdeki metinlerin vahiy mahsulü olup olmadıkları, vahiy metinleri arasındaki teolojik ve yapısal farklılıkların mahiyeti gibi problemler de kelam ilminin konularıdır. Öncesinde tarihsel olarak vahyin korunmasının imkân ya da imkânsızlığı üzerinde durmanın yararlı olacağı kanaatindeyiz.

\section{Tevrat ve Korunması Meselesi}

\subsection{Teknik Açıdan Korunabilmesinin İmkânı}

Tevrat'in korunması meselesinden önce tarihsel olarak böyle bir şeyin imkânı üzerine düşünülmesi gerekir. Zira M.ö. 4000-2000 yılları arasında varlık gösteren Sümerlerle ${ }^{2}$ başladığı varsayılan yazının tarihsel serüvenine baktığımız zaman ilk bașta nesnenin resimlerle anlatıldığı bir yazı formu karşımıza çıkmaktadır. Zamanla resimlerden Mısır hiyerogliflerine oradan da Fenikelilere (M.Ö. 2500'lü yıllar) nispet edilen 26 harfli alfabe sistemine geçilmişti. Tevrat'ın Hz. Mûsâ'ya nüzûlünün ise tarihsel olarak M.Ö. 1310-1271 yıllarına tekabül ettiği düşünülmektedir. ${ }^{3}$ Dolayısıyla Hz. Mûsâ’nın yaşadığı çağlara gelince alfabe seviyesinde bir yazı kültürünün varlığı anlaşılmakla birlikte dönemin doğal şartları, insanlığın yazıyla ilişkisi, yazı aletleri ve yazı formlarıyla eldeki metni yazıyla kayıt altına alma imkânının oldukça iptidai seviyede olduğu söylenebilir. Mevcut verilere göre söz konusu dönemde yazı aletlerinin henüz gelişmemiş olduğu, en elverişlisinin ise dörtgen biçimindeki tahta ya da taştan yapılmış levhalar (tabletler) olduğu anlaşılmaktadır. Nitekim gerek Kur'an'da ${ }^{4}$ gerekse Tevrat'ta ${ }^{5}$ ilâhî mesajın Hz Mûsâ'ya levhalar halinde verildiği belirtilmektedir. Tevrat'ta söz konusu levhanın taştan yapıldığına ve vahyin bu levhalar üzerine oyma yazılarla yazılmış bir halde doğrudan Tanrı tarafından verildiğine değinilmektedir. Her ne kadar Tevrat'ta Mûsâ'nın “Yasa Kitabı"nı yazdığı ve bu kitabı ahid sandığının yanına koyması için Levili kâhinlere teslim ettiği ifade edilmekte ise de ${ }^{6}$ sonraki döneme dair bilgi veren bölümlerde Hz. Süleyman zamanında bu sandığın açıldığı ve Mûsâ'nın koyduğu iki taş levhadan başka bir şey çıkmadığı belirtilmektedir. Çıkan bu levhalardaki yazıların ise büsbütün Tevrat metni olmayıp yalnızca Mısır'dan çıkarken Rabb'in İsrâiloğullarıyla yaptığı anlaşmayı (on emir) ihtiva ettiği anlaşılmaktadır.7 Böylece Hârûnî (Levili) kâhinde çok az bir

2 Sümer kökenli Gılgamış Destanında Nuh tufanından bahsedilmesi ardından da Mısır hiyeroglif yazısının çözülmesi, ilk yazılı metin olarak Ahd-i Atîk'i kabul eden dindar Hıristiyanlar arasında inanç krizine ve bunalıma sebep olmuştur. Bkz. İhsan Fazlığlu, Sözün Eşiğinde (İstanbul: Papersense Yayınları, 2015), 44.

3 Ömer Faruk Harman, "Mûsâ", Türkiye Diyanet Vakfi İslam Ansiklopedisi (İstanbul: TDV Yayınları, 2006), 31/209.

4 "Levhalarda Mûsâ için her konuya dair öğüdü ve her şey hakkında gerekli açıllamaları yazdık. (Ve dedik ki:) "Bunlara sımsıkı sarıl; kavmine de o en güzel ögüt ve açıllamalara sarılmalarını emret. Yakında size yoldan çıkmışların yurdunu göstereceğim" (el-A'râf 7/145).

5 “Rab Mûsầya, 'Dağa, yanıma gel!' dedi, 'burada bekle, halkın öğrenmesi için üzerine yasalarla buyrukları yazdığım taş levhaları sana vereceğim." Kutsal Kitap: Eski ve Yeni Antlasma (Tevrat, Zebur, İncil). (İstanbul: Kitab-1 Mukaddes Şirketi, 2016), Çık.24:12. Yine aynı kitabın 32. babında Mûsâ'nın bizzat Tanrı tarafından yazılmış iki taş levhayla dağdan indiği belirtilmekte, levhaların üzerindeki oyma yazılar da Tanrı'ya izafe edilmektedir (bk. Çık.32:15). Ardından Hz. Mûsâ'nın öfkeyle yere vurup bu taş levhaları parçaladığı anlatılır (bk. Çık.34:19). Hz. Mûsâ’nın tekrar Rabbin huzuruna gitmesi ve kırdığ levhalardaki bilgileri yeniden yazma işlemi ise şu ifadelerde olduğu gibi yine Tanrı'ya atfedilir: "Rab Mûsâ’ya, 'Öncekiler gibi iki taş levha kes' dedi. 'Kırdığın levhaların üzerindeki sözleri onlara yazacağım.” (Çı. $\mathrm{k} .34: 1)$

6 Yas.30:9-24-25.

$7 \quad 1 \mathrm{Kr} .8: 9$. 
bölümü bulunan Tevrat nüshası dışında metninin orijinalinin nesilden nesile yazılı halde aktarıldığını ispatlayabilmek mümkün görünmemektedir. ${ }^{8}$

Otantikliği açısından ele aldığımız Tevrat'tan kasıt Ahd-i Atik'in “Esfâr-1 Hamse” bölümü, yani ilk beş kitabıdır. Zira bilindiği üzere Ahd-i Atik bir kitaplar mecmuasıdır. Bu kitapların her biri farklı uzunlukta değişik türde kitaplar olup dokuz asrı aşkın bir sürede sözlü rivayete dayalı olarak farklı dillerde yazılmışlardır. En son şeklini ise M.S. I. asırda aldığı düşünülmektedir. ${ }^{9}$ Dolayısıyla Tevrat'ın ilk beş bölümü dışındakiler iki bin yılı aşkın bir süreçte rivayetten rivayete, tercümeden tercümeye nakledilmiş ve bu durumun doğal bir neticesi olarak tashih ve sentezlere maruz kalmıştır. ${ }^{10}$ İlk beş bölümün de aynı akıbete duçar olduğunu söylemek mümkündür. Zira üç bin senelik bir din olan Yahudiliğin 11 asırdan daha evvel yazılmış bir nüshasının olmaması, ${ }^{11}$ eldeki nüshaların çelişik, tutarsız ve pek çok ahlaki illetlerle malul olması nedeniyle Tevrat nüshalarının az bir kısmı hariç uzun zaman zarfında değiş̧tirildiği anlaşılmaktadır. ${ }^{12}$

\subsection{Siyasi ve Sosyal Şartlar Açısından İmkânı}

Dönemin siyasi ve toplumsal şartları incelendiğinde Tevrat'ın niçin korun-a-madığı konusu daha iyi anlaşılmaktadır. Zira Firavun'un zulmünden kurtarılan İsrâiloğullarının dinde sebatı kısa süre sonra yerini isyana bırakmıştır. Hz. Mûsâ'nın vefatından sonra Yeşû Peygambere liderlik görevi verilmiştir. ${ }^{13} \mathrm{Bu}$ dönemde Ken'an toprakları büyük oranda ele geçirilmiş ve on iki kabileye pay edilmiştir. Yeşû́dan hemen sonra ise İsrâiloğulları bir süre lidersiz kalmış, bu arada kendi dinlerini bırakmışlar yerel kavimlerin tanrılarına (Baal, Aştarot vb.) tapınmaya başlamışlardır. ${ }^{14}$

Yeşû́dan Tâlût (M.Ö. 1040'lı yıllar) zamanına kadar Yahudiler yedi defa irtidat etmişlerdir. ${ }^{15}$ Tâlût'tan sonra Hz. Dâvûd ve Hz. Süleyman'ın (ö. 925) yaklaşık 80 yıl süren hâkimiyetlerinin ardından İsrâiloğulları Kuzeyde İsrâil, güneyde Yahuda olmak üzere iki ayrı krallıkla yönetilmişlerdir. Bunlardan İsrâil krallığı Tevrat öğretisinden saparak putperestliğe yönelmiştir. ${ }^{16}$

Ebû Muhammed Alî b. Ahmed b. Saîd b. Hazm el-Endelüsî İbn Hazm, el-Fasl: Dinler ve Mezhepler Tarihi (metin-çeviri), çev. Halil İbrahim Bulut (İstanbul: Türkiye Yazma Eserler Kurumu Başkanlığl), 1/696; Baki Adam, Yahudi Kaynaklarına Göre Tevrat: (Mahiyeti, Tahrifi ve Yahudi Hayatındaki Yeri) (Ankara: Seba Yayınları, 1997), 77.

9 Maurice Bucaille, Müsbet İlim Yönünden Tevrat İnciller ve Kur'an, çev. Mehmet Ali Sönmez (Ankara: Diyanet İşleri Başkanlığı Yayınları, 1998), 31-34; Sinan Öge, İlahi Kelamın Yapısı (Ankara: Ankara Okulu Yayınları, 2020), 269.

10 Bucaille, Tevrat İnciller ve Kur'an, 26, 39, 81.

11 Osmanlidan Cumhuriyet'e İslam Düşüncesinde Arayışlar, haz. İlyas Çelebi, Ziya Yılmazer (İstanbul: Rağbet Yayınları, 1999), 79.

12 İbn Hazm, el-Fasl, 1/696.

13 Say.27:12-23; Yşu.1:1-2.

14 Hak.2:20-21.

15 İbn Hazm, el-Fasl, 1/670. İbn Hazm Hz. Mûsâ'dan Talût zamanına kadar İsrâiloğullarının yedi defa irtidat ettikleri bu süreci şöyle tarihlendirir: İlk seferinde 8 yıl, ikincisinde 18 yıl, üçüncüsünde 20 y1l, dördüncüsünde 7 yıl, beşincisinde 3 yıldan biraz fazla, altıncısında 18 yıl, yedincisinde ise 40 yıl küfür içerisinde kalmışlardır. Ardından bu şartlarda ilâhî kitabın korunmasının imkânsızlığını ifade için şöyle söyler: "Sadece üç günlük bir yürüme mesafesinde olan küçük bir beldede, imanın reddedildiği ve küfrün hâkimiyetinin sürekli olduğu bu zaman zarfında hangi kitap orijinalliğini muhafaza edebilir? Üstelik yeryüzünde başka bir coğrafyada aynı dine ve kitaba tabi olan tek bir kimse de yok iken." (ìbn-Ḥazm, el-Fasl, 1/670). 
Sonra da Asurlular tarafından ortadan kaldırılmış, kabileler halinde sürgün edilmiştir (M.Ö. 722721).

Yaklaşık bir asır tarih sahnesinde varlık gösteren Yahuda Krallığı ise Bâbilliler'in (Kaldeliler) denetimine girmiş, Yahuda halkının isyanı neticesinde Krallık bütünüyle ortadan kaldırılmış, halk da sürgüne gönderilmiştir (M.Ö. 586-538). ${ }^{17}$ Bu sürgün Yahudi tarihinin ilk büyük sürgünü ve en önemli hadiselerinden biri kabul edilmiştir. ${ }^{18}$

Sürgün hali dışında da Yahudilerin kendi liderleri istikametlerini muhafaza edememişlerdir. Sürekli politeist anlayışa temayül gösteren bir zihniyette olduğu anlaşılan Yahudi kralları da buldukları ilk firsatta dine ait olan ne varsa inkâra kalkışmışlar, küfre yönelmişler, puthaneler inşa ederek açıktan putlara tapmışlardır. Dahası sadece Hârûnî kâhinin yanında ve tapınağının içinde muhafaza edilmeye çalışılan Tevrat ${ }^{19}$ defalarca doğrudan müdahalelere maruz kalmıştır. Mesela Yehuhar isimli kral döneminde Tevrat'ın söz konusu kâhinden alındığı, levhalar üzerindeki Allah'ın isimleri kazınarak silindiği nakledilmektedir. Ardından yönetimi ele alan Elyakim de dini yasaklamakla kalmamış, Tevrat'ı ateşe atarak izlerini ortadan kaldırmıştır. ${ }^{20}$

M.Ö. 538 yılında Persler'in Bâbilliler'i mağlup etmesinin ardından sürgündeki İsrâiloğulları Yahuda'ya davet edilerek yeniden teşkilatlanmalarına izin verilmiştir. Bu süreçte din âlimi Ezrâ'nın dinde reform çabaları etkili olmuştur (M.Ö. 444-398). Bilhassa Ezrâ'nın mevcut nüshaları kaybolan ve Yahuda halkı tarafından unutulan Tevrat kitabı halka okunup açıklanmış, tek tanrı olarak Yahve'ye tapınması resmî inanç şeklinde benimsenmiştir. ${ }^{21}$ Bu yüzden Ezrâ, Yahudi geleneğinde, Tevrat'ın İsâilloğulları'na yeniden kazandırılmasını sağlayan kişi olarak anılmış, bir nevi ikinci Mûsâ muamelesi görmüştür. Akademik çevrelerde ise Ezrâ (420'li yıllar) mevcut haliyle Tevrat'a son şeklini veren redaktör kabul edilmektedir. ${ }^{22}$

Kendilerinin de ittifak ettikleri üzere Yahudilerin daha ilk nesilleri bütünüyle küfre sapmış, uzun yıllar boyunca da açıkça putlara tapmışlardır. Nitekim onların bu sapkınlıkları, defalarca doğru yoldan ayrılışları Tevrat'ta da yer almaktadır. Ayrıca Ezrâ'nın Tevrat'ı Beytülmakdis'in yıkılışının üzerinden yetmiş yıl sonrasına tekabül etmektedir ki bu şartlar altında orijinal nüshanın baki kalması pek mümkün görünmemektedir. ${ }^{23}$ Ayrıca tek bir nüsha buluna geldiği fikrini çürütür mahiyette nakledilen ve mevcut Tevrat'tan farklı olduğu bilinen Sâmirî Tevrat' $1^{24}$ da ayrı bir bahsin konusudur.

Aktarılan tarihsel süreçten de anlaşıldığına göre krallık dönemleri müstesna tutulursa, Tevrat'ın muhafazası için şartların çok da elverişli olduğu söylenemez. En başta yaşanan çöle mahkûmiyet cezasıyla ilk nesilden yalnızca iki kişinin on emir sandığını muhafaza etmesi ve vaat olunan topraklara (arz-1 mev'ûd) kavuşabilmiş olması kendileri açısından büyük bir talihsizliktir.

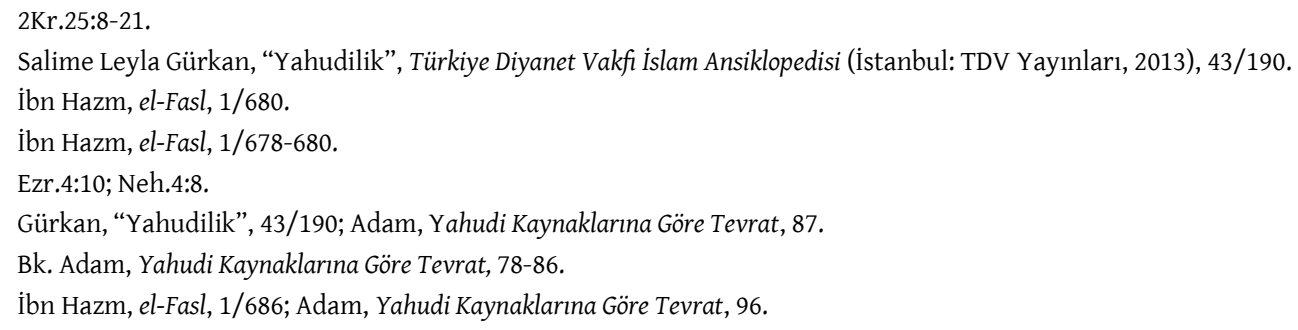


Ardından Yeşû, Şamuel, Dâvûd ve Süleyman gibi önderlerin gelmiş olması ise esasında Tevrat'ın muhafazası için avantaj idi. ${ }^{25} \mathrm{Ne}$ var ki Tevrat'ta da geçtiği üzere Hz. Süleyman, kendisine intikal ettiği söylenilen ahid sandığında yalnızca "on emir"den ibaret olan iki levhadan başka bir şey görememiştir. Üstelik Hz. Süleyman'dan sonra Yahudiler kendi aralarında bölünme, dinden dönme, işgalle birlikte defalarca tehcire, eziyete, zillete ve kültürel tahribata maruz kalmışlardır. Şüphesiz ki bütün bu süreçler sağlıklı bir bilgi aktarımını güçleştiren en önemli unsurlardır. Bu tür dış faktörlerin yanı sıra Yahudilerin kendileri de yaşanan bu tahribatın müsebbipleri konumunda yer almışlardır. Nitekim işledikleri bir kısım kötülüklerden ve ahitlerini bozmalarından ötürü Kur'an'ın lanetini de üzerlerine celp ettikleri davranışlardan bir kısmı, küfür, putlara tapınma, peygamberleri öldürme, Tevrat nüshalarını yakma ve Beytülmakdis'i defalarca yağmalama gibi meş'um hadiselerdir. ${ }^{26}$

Hulasa Tevrat'ın bahsedilen şartlar muvacehesinde sağlıklı bir muhafazası söz konusu ol-amamıştır. Maruz kalınan ağır hezimetler, toplumsal felaketler ve sürgünler sebebiyle yalnızca söze dayalı olarak aktarılan Tevrat metni hakkında ayrıca ilâhî bir koruma tekeffülü de söz konusu değildir. Allah'ın Yahudi halkına emanet ettiği Tevrat metnini koruma imtihanını bu ümmet başarıyla verememiştir. Dolayısıyla günümüzde Eski Ahid (Ahd-i Atik) olarak adlandırılan kitabın az bir kısmı hariç uzun zaman zarfında değişikliğe, ilavelere ve eksiltmelere maruz kaldığı düşünülmektedir. ${ }^{27} \mathrm{Bu}$ yönüyle Tevrat metni ilmin sihhatini zorunlu kilan bir nakille aktarılabilmiş değildir. ${ }^{28}$ İçerisinde peygamberlere isnat edilen büyük günahlar, çelişkili anlatımlar, tarihsel tutarsızlıklar, ${ }^{29}$ tevhit akidesine uymayan ifadeler de bu kanaati destekler mahiyettedir. Keza Batı dünyasında XVI. yüzyıldan itibaren devam eden Kitâb-1 Mukaddes tenkitçiliği hareketi Ehl-i Kitabın kendi kitaplarını tahrif ettiklerine dair Kur'an' da yer alan bilgileri doğrulamaktadır. ${ }^{30}$

\section{Zebûr ve Korunmas1 Meselesi}

Bugün elde mevcut olan Zebûr nüshaları, Yahudi kutsal kitabının (Tanah/Ahd-i Atîk) "Kutsal Yazılar" (Ketuvim) bölümü içinde yer almakta, şiir biçiminde yazılmış 150 ilâhiden oluşmaktadır. Bu metnin de yetmiş üçü Hz. Dâvûd'a nispet edilmektedir. ${ }^{31}$ Icçerisinde yer alan öğütlerin dışında Dâvûd'un (a.s.) Allah'ın oğlu olarak nitelendirilmiş olması, ${ }^{32}$ "Tanrı'nın ilahlar kurulunda” söz

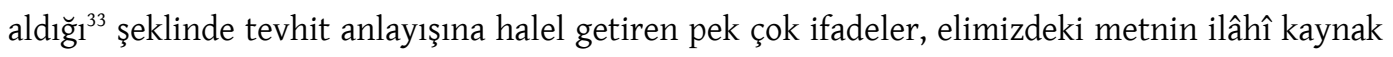
olma vasfını taşımadığını göstermektedir. ${ }^{34}$

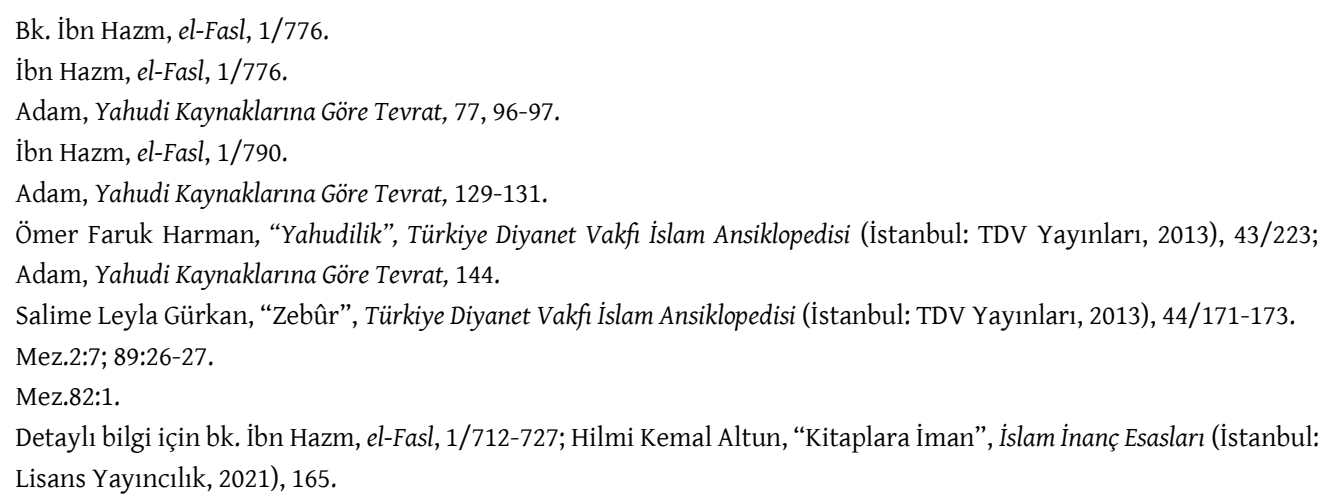




\section{3. İncil ve Korunması Meselesi}

“Iyi haber, müjde" anlamına gelen İncil, İslâmî literatürde Allah tarafından Hz. Îsầya indirilmiş olan kitabın adıdır. ${ }^{35}$ İncil kavramı, muhtevası itibariyle ilâhî kaynaklı diğer metinlerden farklıdır. Şöyle ki Müslüman ve Yahudilerin kutsal metinlerinin otantikliğini ispatlama çabalarına karşın İncil ehli için böyle bir gayret söz konusu değildir. Zira Müslümanların İncil anlayışıyla Hıristiyanların İncil anlayışı birbirinden mahiyet itibariyle farklıdır. İslâm'da İncil'in Allah tarafından Hz. Îsâ'ya indirildiğine inanılır. Bu açıdan Hz. Îsâ'nın diğer peygamberlerden, İncil'in de diğer kutsal kitaplardan farkı yoktur. İncil'in otantikliği meselesi de İslâm açısından ihtimal dışıdır. Zira hem eldeki nüshalar bağlamında ulaşılan tarihsel gerçeklik hem de nüshaların muhtevalarında tevhit akidesine aykırılık arz eden meseleler nedeniyle söz konusu eserlerin orijinal İncil nüshası olarak nitelendirilemeyeceği aşikârdır.

Buna karşın Hiristiyanların nübüvvet-kitap akideleri temel itibariyle Müslümanlardan farklıdır. Onlara göre İncil, diğer kutsal kitaplar gibi yalnızca peygambere inzâl olan vahyi değil Mesîh'in yanı sıra havârilerin de bildirdiği mesajı ifade eder. Nitekim Ahd-i Cedîd yazarları İncil kelimesini "Mesîh tarafından insanlığa getirilen ve havârilerce vaaz edilen kurtuluş müjdesi, Îsâ Mesîh'in doktrini" anlamında kullanmışlardır. ${ }^{36}$ Bu anlamılla İncil, Hıristiyan vahyini ve Îsâ Mesîh vasıtasıyla Tanrı ile insanlar arasında yapılan "yeni ahid"'in şifâhi tebliğini ifade etmektedir. ${ }^{37}$ Ayrıca Tanrı'nın oğlu olan Îsâ Mesîh de, Tanrı'nın sözünü bedeninde taşıyan canlı, yaşayan bir kitaptır. ${ }^{38}$ Başka bir ifadeyle Îsâ Mesîh, Tanrı'nın belirli bir amaç için yüceliğinden soyunarak insan biçiminde görünmesidir. ${ }^{39}$ Yani Îsâ Mesîh, vahyin aktarıcısı değil bizzat kendisidir, Tanrı'nın oğlu ve aynı zamanda 'Tanrı'nın Sözü'dür. İncil de Îsâ'nın kendisidir. Yeni Ahid'i oluşturan Matta, Markos, Luka ve Yuhanna ise dört havariye ait olduğu iddia edilen -Îsâ'yı yorumlayan- müstakil eserlerdir. Bu açıdan Hıristiyanlar için dört farklı isme nispet edilen nüshaların birbirinden farklı olması son derece makul ve izah edilebilir bir durumdur. Zira hiçbirisi doğrudan ve yalnızca Allah'tan gelen vahyi ihtiva etme gibi bir iddia taşımamaktadır. Dolayısıyla eldeki metinlerin bizzat insanlar tarafından oluşturulmasında herhangi bir sakınca da görülmemektedir.

\section{1. İnciller'in Yazıya Geçirilmesi}

Yeni Ahid'i oluşturan dört nüshanın yazıya aktarılmadan önce şifâhi olarak nakledildiğine dair bizzat Hıristiyan bilginlerinin itiraflarına ve eldeki nüshaların mahiyetine ilişkin Hıristiyanların akidesiyle Müslümanların kanaatleri arasındaki farka yukarıda temas edilmişti. Anlaşılan o ki, Yeni Ahid metinleri sözlü olarak aktarılmaya başlanmış ve bu durum bir süre devam etmiştir. Bu arada Hz. Îsâ'nın doğrudan bir yazdırma ya da ezberletme yöntemiyle vahyi korumaya yönelik herhangi bir gayreti bilinmemektedir. ${ }^{40}$ Tam tersine bu süreci şifahi olarak sürdürdüğü anlaşılmaktadır.

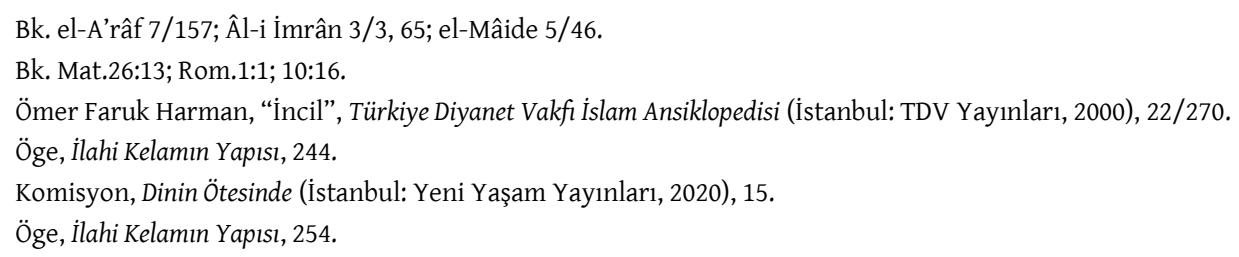


Hz. İsa tarafından aktarılan tebliğin yazıya geçirilme süreci ise Îsâ’nın semaya yükselişinden yaklaşık olarak 65-90 yıl sonrasına tekabül etmektedir. ${ }^{41}$ Bu durumda İncil nüshalarının, Hz. İsa'ya dayandııılan şifahî rivayet ve gelenekler üzerine kurulu bir anlatıma dayandığını söylemek mümkündür. Sözlü süreç boyunca da çeşitli safha ve redaksiyonlara maruz kaldıkları belirtilmektedir. ${ }^{42}$ Yazıya geçirildikten sonra da muhkem bir korumayla muhafaza edilebilmiş değildir. Yazı malzemesi olarak çabuk bozulan, çok hassas bir yazı aleti olan papirüslerin kullanılmış olması bu durumda başlıca etkendir. ${ }^{43}$ Muhtemeldir ki bu nedenle çok küçük birkaç istisna dışında 2. Yüzyıla kadar götürülebilen hiçbir İncil nüshası bulunmamaktadır. ${ }^{44}$ Diğer bir ifadeyle elimizde bulunan Kitab-1 Mukaddes'teki metinler ne Hz. Îsâ'ya indirilen vahyin kendisidir ne de atfedildiği müellifin ilk olarak yazdığı metnin aynısıdır. ${ }^{45}$ Bu durumda mevcut İncillerin ilâhî vahyi temsil ettiğini söylemek de İslâm açısından mümkün değildir. Ancak Hıristiyan akidesine göre insanlar tarafından yazılan bu metinler esasında büsbütün beşerî kaynağa değil ilhama dayalıdır. İncil yazarları Kutsal Ruh'un gözetimi altında O'ndan aldıkları ilhamla ellerindeki metinleri yazmışlardır. Böylece onlara göre ilâhî hüviyeti haiz olan İnciller otantikliğini günümüze değin muhafaza edebilmiştir. Fakat bu bilginin, Hıristiyanlık dininin kendi müntesipleri arasında da genel kabule mazhar olduğunu söylemek zordur. Bu zaviyeden bakınca 393 Hippo Konsili'nin ardından 397 Carthage Konsili'nin tasdikiyle kanonik olmayanların yasaklanmasına dair alınan kararın izahı da mümkün görünmemektedir. ${ }^{46}$ Zira mevcut İncil nüshaları ilâhî kaynağa dayalı bir ilhamla yazılmışsa, beşerin bunlar arasında kanonik-apokrif ayırımı yapma salahiyeti nasıl olabilir? Diğer bir ifadeyle apokrif ilan edilen nüshalar içerisinde "ilhama dayalı sağlam verilerin" göz ardı edilmediğinin garanti edilmesi mümkün müdür?

\section{Kur'an ve Korunması Meselesi}

Çalışmamızın başından beri Kur'an'dan önce insanlığa gönderilen kitapların korunmasına yönelik ilâhî bir teminatın olmadığı; bunun yerine beşeri gayretlerle korunmaya çalışıldığı ancak zamanın teknik, sosyal ve siyasi şartları gereği bu durumun da pek mümkün olmadığı anlaşılmaktadır.

İnsanlığa gönderilen ilâhî kitaplar silsilesinin son halkası durumunda olan Kur'an'ın ise öncekilerden farklı bir özelliği dikkatleri çekmektedir. Tarafsızlığını yitirmemiş, insaf ehli ilim sahiplerinin kabulüne göre Kur'an Allah tarafından Hz. Muhammed'e (s.a.v.) gönderildiği halini muhafaza etmektedir, en ufak bir değişikliğe ve tahrife uğramamıştır. Fakat Kur'an'ın değişmemiş ya da değiştirilememiş olması neye bağlıdır. Yani diğerlerinden farklı olarak Kur'an'ın üzerinde var olan ilâhî garantörlük sebebiyle mi yoksa beşerin zihni tekâmülü, teknik imkânların gelişmişliği, nüzûl ortamının büyük bölümünü ve sonrasını içine alan muktedir bir devlet nizamının kurulabilmiş olması gibi beşerî faktörlerin müessir olduğu bir etken mi söz konusudur?

\footnotetext{
41 Harman, “Íncil”, 22/272.

42 Bucaille, Tevrat İnciller ve Kur'an, 128; Zafer Duygu, İnciller Güvenilir Metinler midir ? (İstanbul: Düşün Yayınc1lık, 2020), 142-163.

43 Duygu, Inciller Güvenilir Metinler midir?, 144.

44 Duygu, Inciller Güvenilir Metinler midir?, 144, 149.

45 Duygu, Inciller Güvenilir Metinler midir?, 142.

46 Öge, İlahi Kelamın Yapısl, 260; Duygu, İnciller Güvenilir Metinler midir ?, 84-86.
} 
Yahut Nazzâm'ın (ö. 231/845) sarfe teorisini ${ }^{47}$ andıran bir durum mu söz konusudur: yani Kur'an, Allah tarafından korunduğu için mi bugüne kadar tahrife uğramadan gelebilmiştir? Yoksa Allah'ın dolaylı iradesi ve izni olmakla birlikte doğrudan müdahil olmadığı bir süreçte daha çok beşerî ve tarihsel faktörlerin öne çıtığı unsurlar sayesinde mi korunmuş, tebdil ve tağyire maruz kalmamıştır? Dolayısıyla her iki halde de Kur'an'ın metin ve lafız itibariyle değişmemiş olduğu hususu müsellemdir. Ancak değişmemenin mahiyeti ve nedeni hakkında fikir teatileri yapılarak farklı yaklaşımlar ortaya konulabileceği görülmektedir. Bu nedenle literatürde Kur'an'ın tebdil ve tağyirden korunduğuna ilişkin sıklıkla zikredilen el-Hicr 15/9 ayetinin doğru anlaşılması önemlidir. Ayetlerin tefsirinde isabetli yoruma ulaşmak için hiç şüphesiz erken dönem bilginlerinin eserlerine bakmak gereklidir. Zira sonraki dönemlerde gerek tefsirin gerekse hadislerin mezhepsel ve ideolojik gayelerle yer yer anlam kaymasına maruz kaldıkları bilinmektedir.

\section{1. el-Hicr 15/9 Ayetinin Değerlendirilmesi}

Allah Teâlâ el-Hicr sûresi 15/9. âyetinde şöyle buyurmaktadır: "Kesin olarak bilesiniz ki bu kitabı (zikri) kuşkusuz biz indirdik ve onu mutlaka koruyan da yine biziz." Ayetin sibak $1^{48}$ müşriklerin alaylı ifadelerle, Hz. Peygamber'e vahiy diye bir şey gelmediği imalarına yer vermekte; esasında onun bir mecnun olduğu, vahiy dediği sözlerin Allah’tan değil cinlerden geldiği ithamlarına işaret etmektedir. ${ }^{49}$ Dolayısıyla bu ifadelerin ardından gelen "korunma ifadesinin" gerek Hz. Peygamber'in mecnun olduğu yönündeki iddiaların reddi gerekse de inzâl olurken cinlerin müdahalesine maruz kalmaktan korunmuş olduğuyla yakın alakalı ve daha çok nüzûl ortamıyla ilgili olduğu anlaşılmaktadır.

$\mathrm{Bu}$ amaçla tefsirlere bakıldığında buradaki "korumanın" hedefine yönelik iki görüş öne çıkmaktadır. Diğer bir ifadeyle “ "s” /lehu'deki zamirin Kur'an’a mı yoksa Hz. Peygamber'e mi râci olduğu noktasında tartışmalar yoğunlaşmaktadır. Zira birinci ihtimale göre Kur'an'ın dış etki ve müdahalelerden; ikinci ihtimalde ise vahyin tenzili sırasında Hz. Peygamber'in cinlerin tasallutundan korunduğu anlaşılmaktadır. Mamafih âyette yer alan korumayı Kur'an'ın “Hz. Peygamber'in kalbinde korunması" olarak değerlendirmek de mümkündür. Nitekim muhtelif âyetlerde Hz. Peygamber'in nüzûl aşamasında unutma endişesi taşıdığından bahsedilmekte ${ }^{50}$ ancak bu tür bir tereddüde mahal olmadığı, inen âyetlerin ona asla unutturulmayacağ $1{ }_{1}{ }^{51}$ kalbine iyice yerleştirileceği gibi ifadelerle Kur'an'ın $\mathrm{Hz}$. Peygamber'in zihninde korunacağ ${ }^{52}$ bildirilmektedir. Görüldüğü üzere bu tür bir koruma da nüzûl süreciyle ilgili olup tarih üstü bir koruma garantisi anlamina gelmemektedir. ${ }^{53}$

47 Kısaca İnkârcılarda potansiyel olarak Kur'an'ın benzerini getirme gücü bulunmakla birlikte Allah tarafindan onların bu gücü kullanmasının engellendiğini ifade eden i'câzü'l-Kur'ân teorisidir. (bk. Yusuf Şevki Yavuz, "Sarfe”, Türkiye Diyanet Vakfi İslam Ansiklopedisi (İstanbul: TDV Yayınları, 2009), 36/140. )

48 "Dediler ki: "Ey kendisine vahiy gelen adam! Sen kesinlikle cinlere kapılmış birisin! Doğru söyleyenlerden isen bize melekleri getirseydin ya! Biz melekleri ancak açık gerçekle indiririz, o zaman da onlara artık süre tanınmaz." (el-Hicr 15/6-8).

49 Hayrettin Karaman, Mustafa Çağrıcı vd., Kur'an Yolu, 3/335-337.

50 Tâhâ 20/114; el-Kiyâmet 75/16-19.

51 el-A'lâ $87 / 6$

52 el-Kıyâmet 75/16-19.

53 Hasan Elik, Kur'ân'in Korunmuşluğu Üzerine (İstanbul: M.Ü. İlahiyat Fakültesi Vakfı Yayınları, 1998), 153-154. 
Şüphesiz doğru anlamın tespiti için iki hususun göz önünde bulundurulması gerekir. Birincisi âyetin konteksti çerçevesinde hangi anlamı çağrıştırdı̆̆ı meselesidir. İkincisi ise henüz mezhepleşme dönemi başlamadan önce yazılan tefsirlerdeki yorumları dikkate almaktır. Kur'an'ın anlaşılmasında ilk muhatapların Kur'an'la olan irtibatları dikkate alındığında hakikate isabet etmek için bu çabanın önemi yadsınamaz. Öte yandan gerek âyetlerin yorumunda gerekse de hadislerin metin ve senetleri konusunda mezhebî sâiklerin tefsir ve hadis alanlarına olan etkileri bilinmektedir. Bu âyetin de erken dönem müfessirlerinin yorumlarında öne çıan anlamıyla sonraki dönemlerde verilen anlam arasında bariz bir fark göze çarpmaktadır. Ayetin zamanla değişen yorumunda böyle bir tesir ihtimali vardır. Zira ilk dönem müfessirleri, âyetin bağlamından hareketle söz konusu korunmayı, daha çok Kur'an'ın Hz. Peygamber'e inzâl süreciyle ilgili anlarken sonraki dönemlerde bu anlayış Kur'an'ın ilelebet korunmasına doğru değişmiştir. Söz gelimi Mukâtil b. Süleyman'ın (ö. 150/767) ilgili âyet hakkındaki yorumu şöyledir: "Allah, peygamberini şeytanlardan koruyacaktır. Çünkü müşrikler Hz. Peygamber'in cinlendiğini ve onların etkisi altında olduğunu iddia ediyorlardı. Cenâb-1 Hak da iddiaları reddetmek için bu âyeti indirdi, böylece cin ve şeytanların O'na asla ilişemeyecekleri ifade edilmiş, Hz. Peygamber bu tür bir etkiden muhafaza edilmiştir. ${ }^{54}$

İlk dönem meşhur Arap dili ve tefsir âlimlerinden Ebû Zekeriyyâ el-Ferrâ da (ö. 207/822) buradaki korumaya yönelik zamirin Kur'an'a ya da aynı şekilde Hz. Peygamber'e râcî olabileceğini belirtmiştir. ${ }^{55}$ Müfessir tarafından “Kur'an'ın ilâhî bir otoriteriyle ilânihaye muhafaza” konusuna hiç temas etmemiş olmasından ve sözün bağlamında hareketle korunmayı nüzûl aşamasında vahyin şeytan tasallutundan korunması ya da Hz. Peygamber'in muhafazası şeklinde yorumladığı anlaşılmaktadır.

Yine ilk dönem önemli muhaddislerinden Abdürrezzâk el-San‘an̂̂’ye (ö. 211/826) nispet edilen tefsirde söz konusu âyetin yorumunda Katâde (ö. 117/735) tarikiyle gelen bilgiye yer verilmektedir. Buna göre Kur'an'ın şeytan tarafından yapılabilecek ziyade ve noksanlığa karşı Allah tarafından muhafaza edildiği belirtilmektedir. ${ }^{56} \mathrm{Bu}$ durumun nüzûl aşamasıyla ilgili bir koruma olduğu açıktır. Böylece ulaşabildiğimiz kadarıyla hicrî III. Asırda yazılan tefsirlerde âyetin anlamı daha çok bu minvaldedir.

Hicrî III. Asırda yaşamış olup IV. Asrın başlarında vefat eden bilginlerden İbn Cerîr et-Taberî (ö. 310/923) bu âyeti, “Allah'ı Kur'an'ı koruyup içine onun aslında bulunmayan bir ifadenin, bir yanlışın karışmasını veya hükümlerinde, hadlerinde, farzlarında bir eksiklik meydana getirilmesini engelleyeceği” şeklinde yorumlamıştır. Akabinde de Katâde'ye nispetle: “Kur'an'ı Allah'ı indirdiği ve şeytanın ona ziyade ve eksiltme teşebbüslerine karşı koruduğu

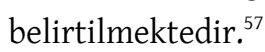

54 Ebü'l-Hasen Mukātil b. Süleymân b. Beşîr el-Ezdî el-Belhî, Tefsîru Mukātil b. Süleymân, thk. Abdullah Mahmûd (Beyrut: Dâru İhyâi't-Türâsi'l-Arabî, 1423), 2/425.

55 Ebû Zekeriyyâ Yahyâ b. Ziyâd b. Abdillâh el-Absî el-Ferrâ', Meâni'l-Kur'ân, thk. Ahmet Yusuf Necati vd. (Misır: Dâru'lMisriyye li't-Te'lîf ve't-Tercüme, ts.), 2/85.

56 Ebû Bekr Abdürrezzâk b. Hemmâm b. Nâfi‘ es-San'ânî el-Himyerî, Tefsîru Abdürrezzâk, thk. Mahmud Muhammed Abduh (Beyrut: Daru'l-Kütübi'l-ilmiyye, 1419), 2/253.

57 Ebû Ca'fer Muhammed b. Cerîr b. Yezîd el-Âmülî et-Taberî, Câmiü'l-beyân an te'vili ayi'l-Kur'an=Tefsirü't-Taberi, thk. Ahmed Muhammed Şâkir (Beyrut: Müessesetü'r-Risâle, 1420), 17/68. 
Taberî ile muasır olan İbn Ebû Hâtim (ö. 327/938) ise Katâde'nin el-Hicr 15/9 âyetini, "Asılsız bir şey ona ne önünden ne arkasından yaklaşabilir. O, hikmet sahibi, övgüye lâyık olan Allah katından indirilmiştir." ${ }^{58}$ âyetiyle tefsir ettiğini nakletmektedir. Ayette geçen "bâtıl" lafzını da "iblis" olarak tefsir etmekte ardından "Allah onu indirdi sonra korudu. İblis ona bir bâtılı eklemeye ve ondan bir hakkı çıkarmaya güç yetiremez. Allah Kur'an'ı bu tür bir müdahaleden korudu" ${ }^{59}$ şeklinde Taberî'de de yer alan yorumu nakletmektedir. Görüldüğü üzere hem Taberî’nin hem de İbn Ebû Hâtim'in yorumlarında Kur'an'ın nüzûl aşamasında şeytanın tasallutundan korunduğuna yönelik yorumlar dikkat çekmektedirler. Buna karşın âyetin Kur'an'ın ilelebet îlâhî bir koruma altında oluşunu ifade ettiğine yönelik kanaatin ilk işaretlerinin Taberî'de yer aldığı belirtilmektedir. ${ }^{60} \mathrm{Ne}$ var ki Taberî’nin bu yorumunda Kur'an'ın hüküm ve yasalarının, yani getirdiği şeriatın korunacağı düşüncesi anlaşılmaktadır. Ayrıca doğrudan Kur'an metninin ilelebet tebdil ve tağyirden muhafaza edileceği gibi bir düşünceye yer verilmemektedir.

İbn Ebû Hâtim ile muasır olan itikatta Ebû Hanîfe'nin usulünü takip eden Mâtürîdî (ö. 333/944) ise Kur'an'ın indiği zamandan beri muarızların itiraz ve tenkit noktası bulamayışlarını Kur'an'ın Allah katından gelme ve korunmuş olma haline işaret olarak değerlendirmektedir. Devamında aynı âyetteki "onu koruyan da yine biziz" ifadesini, "Hz. Peygamber'in Allah tarafindan korunmasi olarak yorumlamakta ve bu koruma işinin Kur'an sayesinde gerçekleştiğini” ifade etmektedir. ${ }^{61}$ Mâtürîdî bu yorumun ardından "bazılarına" atfen yer verdiği ikinci yoruma göre $\mathrm{Hz}$. Peygamber'in bile ancak ilâhî vahiy sayesinde doğru yolu bulabileceği gerçeğine işaret etmektedir. Bu düşünceden hareketle onun hem cin ve şeytan tasallutundan hem de insanların zararından korunmasının Allah tarafından tekeffül edildiği ve bunun da kendisine indirilen Kur'an sayesinde gerçekleştiğini belirtmektedir. ${ }^{62}$ Dolayısıyla Mâtürîdî, Kur'an'ın münzel halinin korunmasına yer verdikten sonra ikinci yorumda korunan şeyin Kur'an değil Hz. Peygamber olduğuna dikkat çekmektedir. Bu itibarla iki hususun ilâhî korumayla ilişkilendirildiği görülmektedir. Birincisi âyetlerin ilâhî olma özelliğine halel getirecek herhangi bir müdahale ya da dış etkiden vahyin korunmasıdır. İkincisi ise Hz. Peygamber'in düşmanlarından korunmasıdır. ${ }^{63}$ Nitekim âyetin bağlamına bakıldığında esas itibariyle müşriklerin vahyin nüzûl aşamalarını ilgilendirecek tarzdaki itirazları reddedilmekte, ardından da vahyin Allah'tan geldiği ve ona şeytandan gelebilecek herhangi bir ilâve ya da eksiltmenin asla söz konusu olamayacağına dikkat çekilmektedir. ${ }^{64}$ İmâm Mâtürîdî, kendisinden önceki teamülün aksine ilk yorumunda Kur'an'ın Mushaf halinin ilelebet korunacağı yönünde bir yoruma yer vermektedir. Bunun dışında âyetteki korumanın Hz. Peygamber'in korunması anlamına da gelebileceğini söylemektedir.

Böylece ilk dönem olarak ifade edebileceğimiz müfessirlerce söz konusu âyetin, Kur'an'in nüzûl aşamasında şeytan ve cin tasallutundan korunarak Hz. Peygamber'in kalbine indirildiği; ayrıca

58 Fussilet $41 / 42$.

59 Abdurrahman b. Muhammed ỉbn Ebû Hâtim, Tefsirü̈l-Kur'âni'l-'azı̂m müsneden 'an Rasûlillah ve's-sahâbe ve't-tâbi în, thk. Esad Muhammed Tayyib (Riyad: Mektebetü Nizâr Mustafa el-Bâz, 1417), 7/2258.

60 Hayrettin Karaman, Mustafa Çağrıcı vd., Kur'an Yolu, 3/335-337.

61 Ebû Mansûr Muhammed b. Muhammed b. Mahmûd el-Mâtürîdî, Te'vîlâtü'l-Kur'an, ed. Yusuf Şevki Yavuz, çev. Yunus Vehbi Yavuz (İstanbul: Ensar Neşriyat, 2020), 8/19.

62 Mâtürîdî, Te'vîlâtül'-Kur'an, 2020, 8/17-19.

63 Ayrıntılı bilgi için bk. Elik, Kur'ân'in Korunmuşluğu Üzerine, 147-151.

64 Hayrettin Karaman, Mustafa Çağrıcı vd., Kur'an Yolu, 3/335-337. 
orada korunduğu ya da Hz. Peygamber'in bizzat kendisinin düşmanlardan gelebilecek bir zarara karşı korunduğu şeklinde anlaşıldığı görülmektedir. Mâtürîlî dışındaki âlimler tarafından âyette ifade edilen korumanın tamamen nüzûl dönemine ait olan bir koruma şeklinde ele alındığı görülmektedir. Mâtürîdî ise her ne kadar Kur'an'ın korunmasını ilk yorum olarak verse de âyetin ikinci yorumu olarak Hz. Peygamber'in korunması fikrini ifade ettiği yönündeki düşünceyi de yadsımamaktadır. Bu itibarla söz konusu korumanın Yüce Allah ile Resulü arasındaki ilişkiye hasredildiğini söylemek doğru olsa gerektir. ${ }^{65}$ Bahsi geçen müfessirlerce konunun izahı sadedinde verdikleri âyetlerin de ${ }^{66}$ aynı doğrultuda bir anlam ifade etmeleri son derece önemlidir. Ayrıca bu kadar önemli bir konuda hadis mecmuaları ve rivâyet tefsirleri başta olmak üzere ilgili yerlerde Hz. Peygamber'e atfedilen "Kur'an'ın ilelebet ilâhî bir muhafaza altında olduğu” yönünde bir rivayetin aktarılmamış olması dikkate şayandır. Dolayısıyla Mâtüridî ile başlayıp ve devam eden bundan sonraki süreçte yazılan tefsirlerde ise âyetin nüzûl aşamalarını ifade eden boyutunun geri planda kaldığı hatta daha çok mushaf/münzel halinin korunmasının kastedildiği gibi bir yoruma evirildiği görülmektedir. Günümüzde de Kur'an'ın korunmuşluğu söz konusu âyet bağlamında ele alınmakta, ayrıca bahsi geçen ilk yorumun üzerinde durulmamaktadır. Bu durumda hiç şüphesiz ki akla ilk gelen husus söz konusu âyetle ilgili tefsirlerin nasıl ikinci anlama evirildiği meselesidir. $\mathrm{Bu}$ noktada muhtemel sebepler tarihsel süreçle birlikte analiz edildiğinde mesele biraz daha vuzuha kavuşmaktadır.

\subsection{Nüzûl Ortamından Uzaklaşılması}

Bilindiği üzere İslâmî ilimlerin tedvin dönemleri -her bir ilim dalı için farklılık gösterse de özellikle tefsir için söyleyecek olursak- Hz. Peygamber'in vefatından yaklaşık olarak bir asır sonrasına tekabül etmektedir. Nüzûl sürecinin çoktan hitama ermesi ve İslâm'ın düşmanlarına açık galibiyetiyle birlikte hiç şüphesiz en başta Hz. Peygamber'in Mekke döneminde muhatap olduğu müşrik toplumun direnci çoktan kırılmış, nüzûlün aşamalarına yönelik daha önceden yapılmış olan tenkit ve iddiaların yersiz olduğu anlaşılmıştır. Dolayısıyla sosyal yapı değişmiş, toplumda Hz. Peygamber'in ne vahiy alma süreciyle ne de mecnun olduğuyla ilgili herhangi bir iddia gündemdedir. Bu itibarla âyetin bağlamı ve aynı zamanda nüzûl ortamı çerçevesinde ilk akla gelen yorumunun karşıllı̆̆ yoktur. Buna karşın âyetin muhtemel ikinci yorumunun, yani Kur'an'ın tüm zamanları kapsayan bir tarzda ilâhî bir koruma altında olduğuna yönelik yorum için toplumsal algı oldukça müsaittir. Hatta ileri sürülen birtakım iddialar bu yorumu gerekli kılmaktadır. Aksi halde Kur'an'in bütünlüğüne yönelik asılsı ithamlar mümin kalplere şüphe düşürmeye son derece elverişlidir. Böyle bir tehlikenin önünü almak için yapılan yorumun da oldukça başarılı bir sonuç verdiğini söylemek mümkündür.

\section{3. Şia'nın Tahrif İddiaları}

Kur'an'ın Hz. Peygamber'e indirildiği şekliyle bugüne değin geldiği, hiçbir tahrife uğramadan eksiklik ve fazlalığa maruz kalmadan muhafaza edildiği İslâm toplumlarının genel kabulü olmakla birlikte tarihte az da olsa farklı ithamlar da dile getirilmiştir. Bu tür ithamların hakikat karşısında tutunamadığını özellikle mezhebî sâikle yapıldığını belirtmekte yarar var. Kur'an ve tahrif iddiası

65 Elik, Kur'ân'ın Korunmuşluğu Üzerine, 153.

66 "Asılsı bir şey ona ne önünden ne arkasından yaklaşabilir. O, hikmet sahibi, övgüye lâyı olan Allah katından indirilmiştir." (Fussilet 41/42); “Allah seni insanlardan koruyacaktır.”(el-Mâide 5/67). 
denilince de akla ilk gelen ekol hiç şüphesiz ki Şîa'dır. Her ne kadar bu tür ithamlar Şiîler arasında genel kabul görmemiş olsa da tarih boyunca bilinen bir gerçek var ki özellikle İmâmiyye'nin Ahbârî koluna mensup bilginler içerisinde bu düşünceyi dile getiren bilginlerin var olageldiğidir. ${ }^{67}$ Meselenin perde arkasinda öncelikle usûlüddîn'den addettikleri imâmet ve velâyet meselesini Kur'an âyetleriyle ispat etme ihtiyacı yatmaktadır. Zira bu akidenin savunulabilmesi ancak Kur'an'ın değiştirildiği iddiasıyla birlikte mümkün olacaktır. ${ }^{68}$ Aksi halde Kur'anî temeli olmayan bir akide ihdas etmiş olma ithamıyla karşı karşıya kalacakları muhakkaktır.

Şîa'nın savunduğu tahrif iddiasının diğer bir amacı da onların sahâbe algılarına dayanmaktadır. Zira Kur'an'da ashâbın ulvî mertebelerine, fazilet ve derecelerine şahitlik eden pek çok âyet yer almaktadır. Hâlbuki onlara göre ashabın birkaçı hariç tamamı, faziletli olmak bir yana lanete müstahak olmuşlardır. ${ }^{69}$

Bu meyanda Şiî akidenin temel kaynakları arasında yer alan Küleynînnin (ö. 329/941) el-Kâfî̀ adlı hadis kitabında Hişam b. Sâlim'in İmâm-1 Ca'fer'den naklen “Cebrâil'in Hz. Peygamber'e on yedi bin âyet indirdiği" ${ }^{\prime 1}$ şeklindeki bir rivayete yer vermektedir. ${ }^{72}$ Rivayetler incelendiğinde görüldüğü üzere -her ne kadar kendi aralarında genel kabul görmese de- Şî̂ler içerisinde dile getirilen mevcut Kur'an üzerinde yapılmış olan bir tahrif iddiasından söz etmek mümkündür. ${ }^{73}$ Yine İmâmiyye Şîası'nda nispeten kabul gören bir anlayışa göre Kur'an'ı ilk cemeden kişi Hz.

67 Nitekim daha geçen asrın başında yaşamış olan Şî'nın itibar ettiği âlimlerden en-Nûrî et-Tabersî (ö. 1320/1903), Faslu'l-hitâb fi tahrîf-i kitâb-ı rabbî'l-arbâ' adlı eserinde Kur'an'ın tahrif edildiğine dair iddiaları tekrar etmektedir.

68 İhsan İlahi Zahir, Şia'nın Kur'an İmamet ve Takiyye Anlayışı, çev. Sabri Hizmetli - Hasan Onat (Ankara, 1984), 70; Ebû Ca‘fer Muhammed b. Ya‘kūb b. İshâk el-Küleynî, el-Kâfi (Beyrut: Menşûrâtü'l-Fecr, 1428), "Kitâbü Fadli'l-Kur'an", 2/332. Küleynînnin söz konusu eserinde bunun dışında pek çok rivayete de yer verilmektedir. Bu rivayetlere bakıldığında elimizdeki Kur'an'dan farklı olan müstakil bir “Fatıma Nüshası”ndan bahsetmek mümkündür. Ayrıca mevcut mushafın pek çok yerinde de tahrifat yapıldığı yönünde iddialar bulunmaktadır.

69 Kādî Abdülcebbâr, Tesbîtü delâili’n-nübüvve, ed. Hüseyin Hansu, çev. Hüseyin Eroğlu - Ömer Aydın (İstanbul: Türkiye Yazma Eserler Kurumu Başkanlığı, 2017), 84-86; Ebü’l-Hasan Nureddin Ali b. Sultan Muhammed Ali el-Kārî, Șemmü’lavârız fi zemmi'r-Revâfiz, thk. Mecid el-Halife (Kahire: Merkezü'l-Furkan li'd-Dirâsâti'l-İslâmiyye, 1425), 83-85; Zahir, Şia'nın Kur'an İmamet ve Takiyye Anlayışı, 42.

70 Küleynî̀nin el-Kâfi adlı eseri, mezhep içerisinde en muteber hadis kitaplarını teşkil eden "kütüb-i erbaa"nın başında gelmektedir. Söz konusu eserin Şiîler nezdindeki klymeti, Sünnîlerin Sahîh-i Buhârîsi mesabesindedir. Bk. ilyas Üzüm, “Kütüb-i erbaa”, Türkiye Diyanet Vakfi İlam Ansiklopedisi (Ankara: Türkiye Diyanet Vakf1, 2003), 27/4.

71 Küleynî, "Kitâbü Fadli'l-Kur'an" 2/350.

72 Mamafih bütün Şiîlerin aynı kanaatte olduğunu söylemek mümkün değildir. Söz gelimi meşhur Şiî müfessir Muhammed Hüseyin Tabâtabâî (1904-1981) Hicr 15/9 ayeti çerçevesinde bizzat Şîi müellifler tarafından yapılan tahrif ve Kur'an'da "velayet sûresi" gibi sûrelerden eksiltme yapıldığı şeklindeki iddiaları kesin bir dille reddetmektedir. ìlgili rivayetleri ise birbiriyle çelişik ve delalet açısından son derece zayıf bulmaktadır. Allâme Muhammed Hüseyin Tabâtabâî, el-Mîzân fî tefsîr'il-Kur'ân (Kum: Cemaati'l-Müderrisin, ts.), 12/114. Dolayısıyla bir kısım muannit ve mutaassıp Şiî tarafından ileri sürülen tahrif iddiasının Şî’nın mutedil müntesipleri katında kabul görmediğini, bu itibarla söz konusu iddianın bütün bir mezhebe teşmil edilmesinin doğru olmadığını söylemek mümkündür.

73 Söz konusu iddiayı savunan Şîi bilginler için bk. Hüseyin Güneş, Tahrif İddiası Bağlamında Şîa ve Kur’an (Konya: Kitap Dünyası Yayınları, 2007), 132-134. 
Ali'dir. ${ }^{74}$ Fakat bu mushaf kayıp halde olup 12. İmamın zuhuruyla birlikte yeniden ortaya çıkacaktır. ${ }^{75}$

Şî̂ akidenin içerisinde bu düşüncenin tam olarak ne zaman ortaya çıktığını kestirmek güç olmakla birlikte söz konusu rivayetlerden anlaşıldığına göre Küleynî'den önce mezhep içerisinde bu yönde süregelen bir rivayet silsilesinde bahsetmek mümkündür. Bu itibarla öncesi hakkında fikir yürütmek zor olsa da en azından H. IV. Asırdan önce mezhep içerisinde bu yönde birtakım kanaatlerin dile getirildiği söylenilebilir. Zira bu dönem aynı zamanda hem Şîa'nın düşünce iklimini şekillendiren hadis ve fikıh ilminin tedvin döneminin sürdüğü hem de -Hasan elAskerî̀nin ölümünden (ö. 260/874) itibaren- mezhebin akidesinin siyasi yönünü oluşturan gaybet, gizli imam ve mehdilik öğretisinin teşekkül ettiği dönemdir. Zira Küleynî’nin bahsi geçen eserini tamamladıktan sonra gizli imam Mehdî el-Muntazar'a gösterdiği ve onun da kitabı beğenerek "Şîamıza kâfidir" dediği rivayet edilir. ${ }^{76}$

Öte yandan "Şîa karşısındaki blok" olarak adlandırabileceğimiz genel dinî hareketi ifade eden Sünnî ekolün bu iddialar karşısında elindeki en büyük koz öncelikle gerek yazıyla gerekse de hıfz yoluyla tevâtüren nakledile gelen Mushaf'ın bizatihi kendisidir. Bunun yanı sıra bahse konu iddialara karşllık, Kur'an'ın ilâhî bir otoriteyle muhafaza edileceği şeklinde yorumlanması kabil olan el-Hicr 15/9 âyetinin de önemli bir karşı argüman olarak kullanıldığı görülmektedir. ${ }^{77} \mathrm{Bu}$ çerçevede Şî’nın Ahbâriyye kolu tarafından dile getirilen tahrif edildiği iddiaları çürütülmüş, Kur'an'ın insanlar tarafından tahrif ve tebdiline bizzat Kelâm'ın sahibi tarafından izin verilmeyeceği savunulmuştur. Böylece üst perdeden bir muhafaza akdinin varlığı ortaya konulmuş, âyetin bu yönde yorumlanmasıyla Kur'an'ın değişmediği ve değiştirilmediği düşüncesi takviye edilmiş, bu sayede muarızların savunma gücü büyük ölçüde kırılmıştır. Bu meyanda zikre değer bir husus da tarih boyunca Kur'an ilimleri üzerinde eser kaleme almış olan Sünnî âlimlerin tavırlarıdır. Söz konusu eserlerde Şiîlerin Kur'an'a yönelik eksik sûre/âyet ithamlarına karşlık bu âyetin (el-Hicr 15/9) doğrudan onlara karşı savunma amacıyla kullanıldığı görülmektedir. ${ }^{78}$

\subsection{Kur'an'in Korunmas1 Nasil Oldu?}

Mademki ilgili âyet doğrudan Kur'an'ın ilâhî bir otorite tarafından korunmayı taahhüdü ifade etmiyorsa peki Kur'an bugüne kadar nasıl korunarak gelmiştir? Bu soruya verilebilecek cevap aslında Kur'an'ın nüzûl tarihini anlatan eserlerde genişçe yer almaktadır. Yani Cenab-1 Hakk'ın Kur'an âyetlerini Hz. Peygamber'e Cebrâil (a.s.) vasıtasıyla indirmesi ve O'nun (s.a.v.) kalbine nakşetmesi bu durumda birinci etkendir. ${ }^{79}$ Nitekim âyette Kur'an'ın Allah tarafından $\mathrm{Hz}$.

74 Ebû Ca'fer Muhammed b. Ya'kūb b. İshâk el- Küleynî, el-Füru' mine'l-Kâfî, nşr. Ali Ekber el-Gaffârî (Tahran: Dâru'lKütübi'l-İslâmiyye, 1388), 1/228; Muhammed es-Seyyid Hüseyin Zehebî, et-Tefsir ve'l-müfessirun (Kahire: Mektebetu Vehbe, 1985), 2/28.

75 Zahir, Şia’nın Kur'an İmamet ve Takiyye Anlayışı, 74-78.

76 Üzüm, "Kütüb-i erbaa”, 27/4.

77 Ali el-Kārî, Şemmü̈l-avârı fi zemmi'r-Revâfiz, 83-85; Abdülazîz b. Şâh Veliyyillâh Ahmed b. Abdirrahîm ed-Dihlevî, Muhtașaru't-Tuhfe-i İsnấaşeriyye, çev. Gulâm Muhammed b. Muhyiddin b. Ömer (Kahire: el-Matbaatü's-Selefiyye, 1373), 30-32.

78 Dihlevî, Tuhfe-i İsnấ‘aşeriyye, 30-32; Ali el-Kārî, şemmü'l-avârız fi zemmi'r-Revâfiz, 83-85; Zehebî, et-Tefsîr ve'l-müfessirûn, $2 / 27-28$.

79 İbrahim Kaplan, Kelam Açııından Tahrifve Kutsal Kitapların Mevsûkiyeti Meselesi (Ankara: Gece Kitaplığı, 2016), 127. 
Peygamber'e okutulduğu bildirilmekte, Hz. Peygamber'in de bu âyetleri ezberinde tutması için çaba sarf etmesine gerek olmadığı, zaten hiçbirisini unutmayacağına dair ilâhî teminat verildiği anlatılmaktadır. ${ }^{80}$ Tam da bu aşamada Kur'an'ın şeytanların tasallutundan korunmuş olduğu hakkındaki teminatının ${ }^{81}$ olduğu da hatırlanmalıdır. Demek ki Kur'an ilk olarak nüzûl aşamasında, şeytanların müdahalesinden korunmuş ardından da Hz. Peygamber'in zihninde muhafaza altına alınmıştır. Buraya kadar ki kısımda ilâhî iradenin faal olduğunda şüphe yoktur. Bundan sonraki süreçte ise başta Hz. Peygamber olmak üzere ardından O'nun izinden giden sahâbe efendilerimizin hıfz ve kitabete yönelik eşsiz gayret ve çabalarının etkili olduğunu söylemek mümkündür. ${ }^{82}$ Öyle ki gelen vahyin vakit kaybedilmeden Hz. Peygamber'den başka sahâbîler tarafindan da ezberlenmesi ve farklı kişilerce yazıya geçirilmesi sayesinde Kur'an çift yönlü olarak, son derece muhkem bir şekilde kayıt altına alınmıştır.

Önceki ilâhî kitaplardan Kur'an'ın farkı ise yukarıdaki korumaya yönelik tedbirlerin yanı sıra nüzûl sürecinin onlardan uzun sürmesi, yazı alet ve kültürünün eskiye nispetle gelişmiş olması, beşerin zihnî tekâmülü sonucu yazının ve kayıt altına almanın öneminin kavranılmış olması gibi etkenler sıralanabilir. Bunlar kadar önemli olan diğer bir husus da tarih faktörüdür ki Hz. Peygamber'in vefatının hemen ardından Mekke ve Medine'de devlet nizamının tesis edilmiş ve sürdürülebilmiş olmasıdır. Diğer bir ifadeyle nüzûl süreci ve sonrasında Müslümanlar tehcir, sürgün, esaret ya da birliklerini ortadan kaldırır nitelikte ağır bir mağlubiyete maruz kalmamışlar, aksine müesses ve aynı zamanda sürdürülebilir bir nizam tesis edebilmişlerdir. Bu sayede eldeki vahyi yazıyla teksir etme ve hıfz yoluyla nesilden nesile aktarabilme fırsatı yakalanmış ve bu fırsat Müslümanlar tarafından azami ölçüde değerlendirilmiştir.

Hâlbuki Tevrat ve İncil'in hem nüzûl süreçleri Kur'an'a nispetle kısa sürmüş, ${ }^{83}$ hem de kayda geçirme süreleri çok daha uzun yıllara yayılmıştır. Bu durumun doğal bir sonucu olarak tebdil ve tağyire elverişli bir ortam adeta kaçınılmaz olmuştur. Kur'an'ın bir bütün olarak değil peyderpey nâzil olması, nüzûl aşamasında hemen yazı ve hıfz yoluyla tesciline imkân tanımıştır. Keza sonrasında da siyasi açıdan sağlıklı bir huzur ortamının varlığı eldeki kayıtların muhafazasını kolaylaştırmış bu sayede Kur'an'ın orijinalliğinin korunması mümkün hale gelebilmiştir. Dolayısıyla Kur'an'ın korunmasında insan ve tarih faktörü oldukça önemlidir. Belki de söz konusu korunmada müessir unsur bu etkenlerdir. Zira -erken dönem müfessirlerinin yorumlarından hareketle- denilebilir ki Allah'ın diğer kitaplardan farklı şekilde Kur'an'a yönelik pozitif ayrımcllık olarak nitelendirilebilecek tarzda tüm zamanlar için hususi bir koruma garantisinden bahsetmek güçtür. ${ }^{84} \mathrm{Ne}$ var ki bu durum -yukarıda da ifade edildiği üzere- Kur'an'ın büsbütün korumasız olduğu anlamına gelmemektedir. Aksine bugüne kadar Kur'an'ın muhafaza edile geldiği

“Onu Sana okutacağız ve unutmayacaksın.” (el-A'lâ 87/6); “Onu zihnine bir an önce kaydetmek için, okumada acele etme. Onu zihninde toplayıp okumanı sağlama işi bize aittir. O halde onu okuduğumuz zaman sen onun okunuşunu takip et. Sonra onu anlatmak elbette bize aittir." (el-Kiyâmet 75/16-19.)

81 el-Hicr 15/9.

82 Ebü'l-Fazl Celâlüddîn Abdurrahmân b. Ebî Bekr b. Muhammed el-Hudayrî es Süyûtî, el-ìtkān fí 'ulûmi'l-Kur'ân, thk. Muhammed Ebü'l-Fazl İbrâhîm (Kahire: el-Heyetü'l-Mırsiyyetü'l-Âmme li'l-Kitâb, 1394), 1/185.

83 Süyûtî, el-itkān, 1/149-155. Sözgelimi Süyûtî, bu eserinde Tevrat'nn inzâlinin Kur'an gibi peyderpey olmadığını, bütünüyle tek bir seferde indirildiğini savunur.

84 Elik, Kur'ân'ın Korunmuşluğu Üzerine, 147. 
bilinmektedir. Lakin bu korumanın faili İlâhî Otorite'nin bizzat Allah'ın kendisi midir? Yoksa Allah'ın iradesi doğrultusunda hareket eden bir takım harici unsurlar mıdır?

El-Müheymin ve el-Müdebbir isimlerinin sahibi olarak kâinattaki cereyan eden her iş hakkında elbette Cenab-ı Hakk'ın izni, iradesi ve muvâfakati vardır. O'na rağmen âlemde bir fiilin işlendiği düşünülemez. Bu itibarla Cenab-1 Hakk'ın Kur'an'ın muhafaza edilmesini murat ettiğini söylemek yanlış olmaz. Fakat bu emir ve iradede beşerî faktör olarak adlandırabileceğimiz sebeplerin müessir unsurlar olarak öne çıktığını dile getirmenin bu hükme aykırı bir yönü yoktur. Bununla birlikte vahiy metinleriyle Kur'an arasında Allah tarafından farklı bir uygulamaya gidilmediği, hepsinin vahiy olması hasebiyle aralarında fark olmadığı şeklinde bir netice hâsıl olmaktadır. Böylece İslâm karşıtlarının Müslümanlara yönelik “Allah tarafından niye sadece Kur'an'ın korunduğu ve diğer vahiylerin korunmadığı” ${ }^{35}$ şeklindeki sualleri yanıtını bulacaktır. Yine "Kur'an'ı koruyan irade pekâlâ öncekileri de koruyabilirdi”" ${ }^{86}$ tarzındaki serzenişlere sebebiyet verilmeyecektir.

Öte yandan gerek Hz. Peygamber'in hayatında gerekse sahâbenin hayatında Kur'an'ın Allah tarafından korunacağı şeklinde emniyet duygusuna rastlanılmamaktadır. Keza Hz. Peygamber'den de Kur'an üzerinde kıyamete kadar sürecek ilâhî garantörlük anlamında bir rivayet de bilinmemektedir. Buna karşın ilk İslam toplumunda Kur'an'ın kaybolma ve zayi olma endişesiyle bu endişe paralelinde hissedilen yoğun bir mesuliyet duygusunun alametleri görülmektedir. Nitekim Hz. Peygamber'in Bi'rimaûne hadisesinin akabinde sergilediği üzüntülü tavır ve günlerce süren bedduasının temelinde hiç şüphesiz yol arkadaşlarına duyduğu hüznün yanında Kur'an'ın hafızalardan silinme endişesi yatmaktadır ${ }^{87}$ Keza Hz. Peygamber'in vefatından sonra da ashabın olağanüstü bir gayret sarf ederek vahyi muhafaza altına almak istemeleri, ${ }^{88}$ Yemâme Savaşı gibi muharebelerde hafızların şehit olmasıyla Kur'an'ın kaybolacağı endişesi taşımaları $\mathrm{da}^{89}$ yine böyle bir mesuliyet duygusundan neşet etmiş olsa gerektir. Üstelik hiç birisinin bu süreçte “Kur'an'ın Allah koruması altında olduğu, böyle bir zahmete girişmenin yersiz olduğu gibi bir düşünceyi serdetmemiş olması da câlib-i dikkattir. Öte yandan Kur'an toplanırken Kureyş lehçesinin esas alındığı bilinmektedir. Bu lehçenin esas alınması ve akabinde diğerlerinin yakılması esnasında öne sürülen gerekçeler yalnızca Kur'an'ın Kureyş lehçesi üzerine nâzil olmasıyla ilişkilendirilmiştir..$^{90}$ Yoksa İlâhî korumanın yalnızca bu lehçeyi tazammun ettiği şeklinde bir gerekçeye yer verilmemiştir. Kezâ Mushafın yazım aşamasında imlâ farklılıklarına yönelik vahiy kâtiplerinin yaptığı tashihleri de tamamen beşerî tercih olarak değerlendirmek mümkündür. Zira hiçbirisinde ezelî bir karara atıf yapıldığına rastlanılmamaktadır. ${ }^{91}$

Ayrıca Hz. Peygamber'in kendi sözlerinin yazılmasını uzun bir süre yasak ettiği ardından da İbrâhim en-Nehâî (ö. 96/704) gibi tâbiîn âlimlerine gelinceye kadarki süreçte "hadis yazımının

85 Kaplan, Kelam Açısından Tahrifve Kutsal Kitapların Mevsûkiyeti Meselesi, 124-125.

86 Kaplan, Kelam Açısından Tahrifve Kutsal Kitapların Mevsûkiyeti Meselesi, 17.

87 İbrahim Tetik, “Nüzul Döneminde Kur’ân Hıfzının Dinsel ve Sosyo-Kültürel Dinamikleri”, Marife Dini Araştırmalar Dergisi 21/1 (2021), 259.

88 Kasım b. Sellâm Ebu Ubeyd, Fezâilu'l-Kur'ân (Beyrut: El-Mektebetü'l-Asriyye, 2009), 95-96.

89 Süyûtî, el-ìtkān, 1/203-205.

90 Ebu Ubeyd, Fezâilu'l-Kur'ân, 96.

91 Ebu Ubeyd, Fezâilu'l-Kur'ân, 95-114. 
Kur'an'la karışır endişesiyle caiz görülmediğgi ${ }^{92}$ bilinmektedir. Hiç şüphesiz bu durum bize, insanların Kur'an'ın korunması meselesine yaklaşımını göstermektedir. Rivayetlere yansıdığı kadarıyla kimsenin bu meseleyi ilâhî otoriteyle ilişkilendirmemesi aksine korumaya yönelik sorumluluğu bizzat kendi omuzlarında hissetmiş olmaları bu uğurda bireysel ve toplumsal koruma sorumluluğunu/refleksinin ön planda çıktığını gösteren önemli işaretlerdir.

Bu bağlamda diğer ilâhî kitaplardan farklı bir meziyet olarak son ilâhî vahyin hıfzının kolay olması zikre değer başka bir husustur. İmâm Mâtüridî, Kur'an'ın ezberinin insana kolaylaştırılmasını, korunmasına yönelik önemli bir faktör olarak değerlendirmekte ve şöyle demektedir: "Cenâb-1 Hak onu okumayı insanların dillerine ve kalplerine kolaylaştırmışıır; o kadar ki, biri ona ziyade veya noksan yapar veya tebdil eder veya bir şeyi tahrif eder veya takdim ve tehir yapacak olsa bu mutlaka bilinir. ${ }^{" 93}$ Bilebildiğimiz kadarıyla tarih boyunca başka hiçbir metin üzerinde görülmeyen bir suhuletle hem ezberlenme hem de ezberin muhafazası açısından Kur'an'ın, hacmine nispetle oldukça kolay hıfzedilebilir olması nevi şahsına münhasır mucizevi bir niteliktir. Nitekim yeryüzünde bütün kitaplar kaybolsa yeniden yazılabilecek tek kitap Kur'an'dır.

Buraya kadar aktarılanlarda da görüldüğü üzere vahiy bütün olarak ele alındığında hiçbir vahiy unsurunun münzel haliyle doğrudan Allah'ın koruması altında olması diye bir hususun olmadığını söylemek mümkündür. Anlaşıldığı kadarıyla vahiy, Levh-i Mahfûz'da ve Peygamberin kalbine indirilme sürecinde Allah'in garantisi ve koruma taahhüdü altında olmakta, mesaj selametle peygambere ulaştırılmakta, ondan sonrası ise beşerin/ümmetin sorumluluğuna bırakılmaktadır. ${ }^{94}$ Nitekim Kur'ân-1 Kerim'de vahyi korumanın ümmetin bilginlerine havale edildiği gerçeği -Tevrat özelinde- şöyle açıklanmaktadır:

“Kendilerini Allah'a vermiş olan peygamberlerin ve -Allah'ın kitabını korumaları kendilerinden istendiği için- rablerine teslim olmuş zâhidlerin, bilginlerin Yahudiler arasında kendisiyle hükmettikleri, içinde hidayet ve nur bulunan Tevrat'i elbette biz indirdik. Hepsi onun (hak olduğunun) şahitleri idi." ${ }^{\prime 95}$

$\mathrm{Bu}$ itibarla esasında inen vahyin muhafazası aynı zamanda ümmetin bir imtihanı olmaktadır. Önceki ümmetler, yüklendikleri bu imtihanda başarılı olamamışlardır. Bu meyanda başarısızlığı tetikleyen faktörlere yukarıda temas edilmişti. Ancak Müslümanlar Kur'an'ın ilk âyetlerinin okuma ve yazmayla olan sıkı münasebetini Hz. Peygamber'in bizzat rehberliği sayesinde doğru kavramışlar ve vahyin korunmasını sağlayacak tedbirlere ağılık vermişlerdir. Yine aynı amaca matuf olarak özellikle hadislerden hareketle Kur'an'ın taliminin yanı sıra ezberlenmesinin de farz1 kifâye olduğu hükmüne varılmıştır. ${ }^{96}$ Dinin tebliğinin önemli bir kısmını oluşturan bu tür bir teşvik ve sorumluluk da hiç şüphesiz Kur'an'in korunmasında oldukça önemlidir.

92 Ebû Muhammed Abdullâh b. Abdirrahmân ed-Dârimî, Müsnedü'd-Dârimî (el-Ma'rûf bi Süneni'd-Dârimî), thk. Hüseyn Selîm Esed ed-Dârânî (Riyâd: Dâru'l-Muğnî, 1412), "Babu men lem yera kitabete'l-hadis", 479.

93 Ebû Mansûr Muhammed b. Muhammed b. Mahmûd el-Mâtürîdî, Te’vîlâtü'l-Kur'an, ed. Yusuf Şevki Yavuz, çev. S. Kemal Sandıkçı (İstanbul: Ensar Neşriyat, 2017), 7/271.

94 Elik, Kur'ân'ın Korunmuşluğu Üzerine, 157.

95 el-Mâide 5/44.

96 Süyûtî, el-ìtkān, 1/343. 
Mamafih şayet mutlak bir korumadan bahsedilecekse, burada bir bütün olarak düşünülmesi gereken geçmiş bütün vahiylerin, vahiy silsilesinin son halkası olan Kur'an ile korunduğu hususuna değinmek gerekir. ${ }^{97}$ Zira Kur'an'ın kendisini tavsif ettiği "musaddik" ve "müheymin" isimlerinde mefhum olarak bu nitelik mevcuttur. Aynı şekilde Kur'an'da "(Resulüm!) Sana da kendisinden önceki kitapları tasdik edici ve onları denetleyici olarak bu kitabı hak ile indirdik." buyurulmaktadır. Bu itibarla Kur'an'ın ve diğer semavî kitapların aynı kaynaktan geldiği belirtilmekte, temel mesajlarının aynı olması hasebiyle Kur'an'ın kendisinden önceki ilâhî kitapları tasdik ettiği vurgulanmış olmaktadır. ${ }^{99}$

\section{Sonuç}

Vahyin korunmuşluğu çerçevesinde yapılan tahlillerde de görüldüğü üzere kendilerine ilâhî metin hüviyeti atfedilen Kur'an dışındaki metinlerin hiç birisi ilmin sıhhatini zorunlu kılan bir nakille aktarılabilmiş değillerdir. Kur'an'ın Allah tarafından Hz. Peygamber'e nâzil olduğu haliyle muhafaza edildiği konusunda ilim çevrelerinde büyük bir uzlaşı vardır. Bu çerçevede ileri sürülen birtakım asılsız iddialar mutaassıp mezhep mensupları tarafından yapılmakta, bu yönüyle ilmi bir hüviyet taşımamaktadır. Nitekim tarihin doğal seyri içerisinde bu iddialar savunulabilirliğini kaybetmiş ve büyük ölçüde Müslümanların gündeminden düşmüştür. Dolayısıyla genel kabule göre Kur'an Hz. Peygamber'e indirildiği şekliyle bir kelime ya da harf dahi değiştirilmeden günümüze kadar gelmiştir. Ne var ki Kur'an'in bu halini muhafaza etmesinde faal unsur doğrudan İlâhî Otorite midir yoksa tarihi ve beşerî faktörler midir, sorusu cevaplanmalıdır. Aksi takdirde niye sadece Kur'an'ın korunup diğer kitapların korunmadığı, onların önemsiz mi görüldüğü gibi bir takım sorularla karşılaşılmakta ve bu sorulara tatminkâr cevaplar verilememektedir. Ayrıca söz konusu kutsal metinlerin her ne kadar isimleri ve nüzûl zamanları farklı olsa da temelde Allah'ın ilmine konu olması, Allah-zaman ilişkisi ve Levh-i Mahfûz'da yer almaları açısından aralarında hiçbir fark olmasa gerektir.

Kutsal metinler arasındaki bu temel teolojik birlikteliğe rağmen Kur'an'ın orijinalliğini koruyor olmasıyla alakalı el-Hicr 15/9 âyeti etrafında yapılan yorumlar dikkatleri üzerine çekmektedir. Bu âyeti yorumlayan erken dönem müfessirleri, Kur'an'la ilgili daha çok nüzûl sürecini ilgilendiren bir koruma anlamı vermişlerdir. Bu bağlamda vahyin iniş aşamasında şeytanın tasallutundan korunması, Hz. Peygamber'in korunması ya da vahyin Hz. Peygamber'in zihninde korunması şeklinde söz konusu korunma detaylandırılmıştır. Ardından gelen ikinci-üu̧üncü dönem müfessirleri ve onların takipçileri ise Kur'an metninin kıyamete değin tebdil ve tahriften korunacağı ve âyetin bu koruma garantisi anlamına geldiği şeklindeki bir anlam üzerinde ittifak etmişlerdir. Bu meyanda âyetin nüzûl sürecindeki muhafazasına ilişkin yorumların geri planda kaldığı görülmektedir. Tefsirlerde söz konusu âyetin yorumundaki bu değişikliğin sebeplerinin neler olabileceği noktasında yaptığımız çalışmada iki temel nedene ulaştık. Birincisi nüzûl ortamından uzaklaşılmış olmasıdır. Nitekim zamanın değişmesiyle problemler de değişmektedir. Kur'an'ın indiği dönemde nüzûl süreçlerine ve doğrudan Hz. Peygamber'e cinlerin musallat olduğu gibi iddialar ve bu iddiaların izalesi gündemde iken sonrasında Kur'an'ın Mushaf haline

97 Kaplan, Kelam Açısından Tahrifve Kutsal Kitapların Mevsûkiyeti Meselesi, 16, 86, 99.

98 el-Mâide 5/48.

99 Hayrettin Karaman, Mustafa Çağrıcı vd., Kur'an Yolu, 2/285-288. 
yönelik şüpheler gündemi meşgul eder hale gelmiştir. Doğal olarak nüzûl sürecine ve $\mathrm{Hz}$. Peygamber'in şahsına yönelik iddiaların asılsızlığı tebellür etmiş, ancak Kur'an'ın Mushaf haline yönelik iddialar artmıştır. Bu itibarla ikinci neden, Kur'an'dan eksik sûre ya da âyet iddialarına karşllık söz konusu âyetin cevap mahiyetinde yorumlanması son derece işlevsel bir taktik olarak göze çarpmaktadır. Diğer bir ifadeyle din ve toplum psikolojisi âyetin bu şekilde yorumunu adeta icbar etmiştir. Dolayısıyla tefsirlerde söz konusu âyet bağlamında değişen yorum farkının temelinde mezhebî sâiklerin olduğunu söylemek mümkündür. Mamafih âyetin bağlamı dışında, özellikle gramatik ve dil yapısı bu tür bir yorum için elverişlidir. Ancak hiç şüphesiz bağlam ve nüzûl ortamı âyetin doğru anlaşılması için daha önemlidir. Öte yandan yapılan bu tür bir yorumla başta Hz. Peygamber olmak üzere O'nun izinden giden sahâbe efendilerimizin ve sonrasındaki bütün ümmetin hıfz ve kitabete yönelik eşsiz gayret ve çabalarının kısmen göz ardı edildiğini söylemek mümkündür. Dolayısıyla âyette Kur'an'ın korunma sürecini anlatan ifadeler -özellikle erken dönem müfessirlerinin kanaatinden hareketle- nüzûl aşamasını ifade etmektedir. Buna ilave olarak Hz. Peygamber'in Kur'an'ın bizzat Allah tarafından ilânihaye muhafaza edileceği yönünde bir beyanı bilinmemektedir. Bu itibarla Kur'an da diğer ilâhî kitaplar gibi nüzûl aşamasında korunarak Hz. Peygamber'e aktarılmıştır. Sonrasında da diğer kitaplarla aynı muameleye tabi olmuş, onlara nispetle pozitif bir ayırımcllı̆̆a/iltimasa konu olmamıştır. Kısaca mutlak olarak vahyin korunması, nâzil olduğu toplumun/ümmetin uhdesine havale edilmiş, koruma vazifesi bir tür imtihan/sorumluluk olarak gönderildiği toplumun omuzlarına yüklenmiştir. Geçmiş ümmetler bu imtihanı kaybetmişler, İslâm ümmeti ise bu güne kadar kazanarak gelmiştir. Bundan sonrası için de ümmetin imtihanı ve sorumluluğu devam etmektedir. 


\section{Kaynakça}

Adam, Baki. Yahudi Kaynaklarına Göre Tevrat: (Mahiyeti, Tahrifi ve Yahudi Hayatındaki Yeri). Ankara: Seba Yayınları, 1997.

Ali el-Kārî, Ebü'l-Hasan Nureddin Ali b. Sultan Muhammed. Şemmü'l-avârız fi zemmi'r-Revâfiz. thk. Mecid el-Halife. Kahire: Merkezü'l-Furkan li'd-Dirâsâti'l-i̇slâmiyye, 1425.

Altun, Hilmi Kemal. “Kitaplara İman”. İslam İnanç Esasları. İstanbul: Lisans Yayıncılık, 2021.

Belhî, Ebü'l-Hasen Mukātil b. Süleymân b. Beşîr el-Ezdî. Tefsîru Mukātil b. Süleymân. thk. Abdullah Mahmûd. Beyrut: Dâru İhyâi't-Türâsi'l-Arabî, 1423.

Bucaille, Maurice. Müsbet İlim Yönünden Tevrat İnciller ve Kur'an. çev. Mehmet Ali Sönmez. Ankara: Diyanet İşleri Başkanlığı Yayınları, 6. Basım, 1998.

Dârimî, Ebû Muhammed Abdullâh b. Abdirrahmân. Müsnedü'd-Dârimî (el-Ma'rûf bi Süneni'd-Dârimî). thk. Hüseyn Selîm Esed ed-Dârânî. 4 Cilt. Riyâd: Dâru'l-Muğnî, 1412.

Dihlevî, Abdülazîz b. Şâh Veliyyillâh Ahmed b. Abdirrahîm. Muhtașaru't-Tuhfe-i İsnấ'aşeriyye. çev. Gulâm Muhammed b. Muhyiddin b. Ömer. Kahire: el-Matbaatü's-Selefiyye, 1373.

Duygu, Zafer. İnciller Güvenilir Metinler midir? İstanbul: Düşün Yayınc1lık, 2020.

Ebu Ubeyd, Kasım b. Sellâm. Fezâilu'l-Kur'ân. Beyrut: El-Mektebetü'l-Asriyye, 2009.

Elik, Hasan. Kur'ân'ın Korunmuşluğu Üzerine. İstanbul: M.Ü. İlahiyat Fakültesi Vakfı Yayınları, 1998. Fazlıoğlu, İhsan. Sözün Eşiğinde. İstanbul: Papersense Yayınları, 2015.

Ferrâ', Ebû Zekeriyyâ Yahyâ b. Ziyâd b. Abdillâh el-Absî el-Ferrâ'. Meâni'l-Kur'ân. thk. Ahmet Yusuf Necati vd. 3 Cilt. Misır: Dâru'l-Mısriyye li't-Te'lîf ve't-Tercüme, ts.

Güneş, Hüseyin. Tahrif İddiası Bağlamında Şia ve Kur'an. Konya: Kitap Dünyası Yayınları, 2007.

Gürkan, Salime Leyla. "Yahudilik". Türkiye Diyanet Vakfi İslam Ansiklopedisi. 43/187-197. İstanbul: TDV Yayınları, 2013.

Gürkan, Salime Leyla. "Zebûr”. Türkiye Diyanet Vakfi İslam Ansiklopedisi. 44/171-173. İstanbul: TDV Yayınları, 2013.

Harman, Ömer Faruk. “İncil”. Türkiye Diyanet Vakfi İslam Ansiklopedisi. 22/270-276. İstanbul: TDV Yayınları, 2000.

Harman, Ömer Faruk. "Mûsâ". Türkiye Diyanet Vakfi İslam Ansiklopedisi. 31/207-213. İstanbul: TDV Yayınları, 2006.

Harman, Ömer Faruk. "Yahudilik”. Türkiye Diyanet Vakfi İslam Ansiklopedisi. 43/220-226. İstanbul: TDV Yayınları, 2013.

Hayrettin Karaman, Mustafa Çağrıcı vd. Kur'an Yolu Türkçe Meal ve Tefsir. 5 Cilt. Ankara: Diyanet İşleri Başkanlığı Yayınları, 2. Basım, 2006. 
Himyerî, Ebû Bekr Abdürrezzâk b. Hemmâm b. Nâfi‘ es-San'ânî. Tefsîru Abdürrezzâk. thk. Mahmud Muhammed Abduh. 3 Cilt. Beyrut: Daru'l-Kütübi'l-İlmiyye, 1419.

İbn Ebû Hâtim, Abdurrahman b. Muhammed. Tefsîrül'-Kur'âni'l-'azim müsneden 'an Rasûlillah ve'ssahâbe ve't-tâbi în. thk. Esad Muhammed Tayyib. 13 Cilt. Riyad: Mektebetü Nizâr Mustafa el-Bâz, 1417.

İbn Hazm, Ebû Muhammed Alî b. Ahmed b. Saîd b. Hazm el-Endelüsî. el-Fasl: Dinler ve Mezhepler Tarihi (metin-çeviri). çev. Halil İbrahim Bulut. 3 Cilt. İstanbul: Türkiye Yazma Eserler Kurumu Başkanlığı, 2017.

Kādî Abdülcebbâr. Tesbîtü delâili’n-nübüvve. ed. Hüseyin Hansu. çev. Hüseyin Eroğlu - Ömer Aydın. İstanbul: Türkiye Yazma Eserler Kurumu Başkanlığı, 2017.

Kaplan, İbrahim. Kelam Açısından Tahrif ve Kutsal Kitapların Mevsûkiyeti Meselesi. Ankara: Gece Kitaplığı, 2016.

Komisyon. Dinin Ötesinde. İstanbul: Yeni Yaşam Yayınları, 2. Basım, 2020.

Küleynî, Ebû Ca'fer Muhammed b. Ya'kūb b. İshâk. el-Füru' mine'l-Kâfí. nşr. Ali Ekber el-Gaffârî. Tahran: Dâru'l-Kütübi'l-İslâmiyye, 1388.

Küleynî, Ebû Ca'fer Muhammed b. Ya'kūb b. İshâk. el-Kâfi. 8 Cilt. Beyrut: Menşûrâtü'l-Fecr, 1428.

Mâtürîdî, Ebû Mansûr Muhammed b. Muhammed b. Mahmûd. Te'vîlâtü'l-Kur'an. ed. Yusuf Şevki Yavuz. çev. S. Kemal Sandıkçı. İstanbul: Ensar Neşriyat, 2017.

Mâtürîdî, Ebû Mansûr Muhammed b. Muhammed b. Mahmûd. Te'vîlâtü'l-Kur'an. ed. Yusuf Şevki Yavuz. çev. Yunus Vehbi Yavuz. İstanbul: Ensar Neşriyat, 2020.

Öge, Sinan. İlahi Kelamın Yapısı. Ankara: Ankara Okulu Yayınları, 2. Basım, 2020.

Süyûtî, Ebü'l-Fazl Celâlüddîn Abdurrahmân b. Ebî Bekr b. Muhammed el-Hudayrî. el-ìtkān fî 'ulûmi'l-Kur'ân. thk. Muhammed Ebü'l-Fazl İbrâhîm. Kahire: el-Heyetü'l-Mırsiyyetü'l-Âmme li'lKitâb, 1394.

Tabâtabâî, Allâme Muhammed Hüseyin. el-Mîzân fî tefsîr'il-Kur'ân. 20 Cilt. Kum: Cemaati'lMüderrisin, ts.

Taberî, Ebû Ca'fer Muhammed b. Cerîr b. Yezîd el-Âmülî. Câmiü'l-beyân an te'vili ayi'lKur'an=Tefsirü't-Taberi. thk. Ahmed Muhammed Şâkir. 24 Cilt. Beyrut: Müessesetü'r-Risâle,1420.

Tetik, İbrahim. “Nüzul Döneminde Kur'ân Hıfzının Dinsel ve Sosyo-Kültürel Dinamikleri”. Marife Dini Araştırmalar Dergisi 21/1 (2021), 253-277.

Üzüm, İlyas. "Kütüb-i erbaa". Türkiye Diyanet Vakfi İslam Ansiklopedisi. 27/4-6. Ankara: Türkiye Diyanet Vakfi, 2003.

Yavuz, Yusuf Şevki. "Sarfe”. Türkiye Diyanet Vakfi İslam Ansiklopedisi. 36/140-141. İstanbul: TDV Yayınları, 2009.

Zahir, İhsan İlahi. Şia’nın Kur'an İmamet ve Takiyye Anlayışı. çev. Sabri Hizmetli - Hasan Onat. Ankara, 1984. 
Zehebî, Muhammed es-Seyyid Hüseyin. et-Tefsîr ve'l-müfessirûn. Kahire: Mektebetu Vehbe, 1985.

Kutsal Kitap: Eski ve Yeni Antlasma (Tevrat, Zebur, İncil). İstanbul: Kitab-1 Mukaddes Şirketi, 2016.

Osmanli'dan Cumhuriyet'e İslam Düşüncesinde Arayışlar. haz. İlyas Çelebi, Ziya Yılmazer. İstanbul: Rağbet Yayınları, 1999. 